Ocean Sci. Discuss., https://doi.org/10.5194/os-2017-50

Manuscript under review for journal Ocean Sci.

Discussion started: 16 August 2017

\title{
About the origin of the Mediterranean Waters warming during the twentieth century.
}

María del Carmen García-Martínez ${ }^{1}$, Manuel Vargas-Yáñez ${ }^{1}$, Francina Moya ${ }^{1}$, Patricia Zunino ${ }^{2}$, Begoña Bautista ${ }^{3}$

$5 \quad{ }^{1}$ Instituto Español de Oceanografía. Centro Oceanográfico de Málaga. Puerto pesquero de Fuengirola. 29640, Fuengirola (Málaga), Spain.

${ }^{2}$ CNRS, Ifremer, Univ. Brest, IRD, Laboratoire d'Océanographie Physique et Spatiale (LOPS), IUEM, Plouzané, France

${ }^{3}$ Universidad de Málaga. Departamento de Ecología, Facultad de Ciencias, Campus Universitario de Teatinos s/n. 29010 (Málaga), Spain

Correspondence to: M.C. García-Martínez (mcarmen.garcia@ma.ieo.es)

Abstract The Mediterranean Sea transforms Atlantic Waters inflowing through the Strait of Gibraltar into saltier, cooler and denser Mediterranean Waters that outflow into the Atlantic Ocean. A theoretical steady state functioning of the Mediterranean Sea would be the result of the balance between the net heat and volume transports through the Strait of Gibraltar and the heat loss to the atmosphere through the sea surface and the net evaporation. The salt transport for the inflow and outflow should be balanced. Changes in the heat content, temperature and salinity of the Mediterranean waters reveal that the present Mediterranean functioning is out of this equilibrium state. A new analysis for MEDAR data shows that the temperature and salinity averaged for the Mediterranean Waters in the whole basin increased at rates of $0.0020 \pm$ $0.0018^{\circ} \mathrm{C} / \mathrm{yr}$ and $0.0007 \pm 0.0003 \mathrm{psu} / \mathrm{yr}$. This temperature trend is equivalent to a $0.43 \pm 0.38 \mathrm{~W} / \mathrm{m}^{2}$ heat absorption. This warming trend would have increased during the beginning of the twenty first century at the Western Mediterranean, maybe linked to the Western Mediterranean Transition. Results from a simple box model using heat, volume and salt conservation laws indicate that the observed changes cannot be attributed only to an increase of the net evaporation, nor to a salinity increase of the Atlantic Waters flowing through the Strait of Gibraltar as previous hypotheses suggested. An increase of the net evaporation ranging between 5 and $7 \%$ combined with a reduction of the heat losses to the atmosphere ranging between 0.4 and $0.5 \mathrm{~W} / \mathrm{m}^{2}$ could explained the observed changes.

Key words: Temperature and salinity trends, climate change, Mediterranean Sea. 
Ocean Sci. Discuss., https://doi.org/10.5194/os-2017-50

Manuscript under review for journal Ocean Sci.

Discussion started: 16 August 2017

(c) Author(s) 2017. CC BY 4.0 License.

The temperature and salinity of the Mediterranean waters have increased along the twentieth century with an acceleration of the warming and salting trends during the second half of the century (Rohling and Bryden, 1992; Vargas-Yáñez et al., 2010). Because of its reduced dimensions and its semi-enclosed character, it has been considered that the Mediterranean Sea could be especially sensitive to climate change and other anthropogenic effects (Bethoux et al., 1999).One of the first works dealing with such changes was the one by Lacombe et al. (1985). These authors compared previous data from several oceanographic cruises carried out from 1950 to the end of the 1970s concluding that the temperature and salinity of the Western Mediterranean Deep Waters (WMDW) had increased. After this pioneering work, many others have attempted to estimate the changes in temperature and salinity for the different water masses and regions within the Mediterranean Sea, trying to explain the causes of such changes. Nevertheless, the analysis of existing data has led to some discrepancies. Summarizing the main findings: both temperature and salinity of WMDW have increased along the twentieth century (Vargas-Yáñez et al., 2010; Rixen et al., 2005; Bethoux et al., 1999; Krahmann and Schott, 1998; Rohling and Bryden, 1992). Some works have found positive trends for the salinity of the Levantine Intermediate Water (LIW, Rixen et al., 2005; Bethoux et al., 1999 ; Rohling and Bryden, 1992). Other works consider that the LIW salinity has not changed along the twentieth century (Painter and Tsimplis, 2003). Some studies have reported positive temperature trends for the LIW (Bethoux et al., 1999; Sparnocchia et al., 1994) while others consider that the temperature of this water mass only exhibits decadal variability or even decreasing trends (Rixen et al., 2005; Krahmann and Schott, 1998; Painter and Tsimplis, 2003). Concerning Atlantic Waters (AW), Krahmann and Schott (1998), Sparnocchia et al. (1994) found no changes in its temperature. On the contrary, Salat and Pascual (2006), Skliris et al. (2012) reported the warming of this water mass from the mid 1970s. Finally, Krahmann and Schott (1998) reported positive salinity trends for the AW while Sparnocchia et al. (1994) found no changes for the salinity of this water mass. More recent works have evidenced by means of satellite infrared data the warming of the surface layer, both in the Western and Eastern Mediterranean (WMED and EMED) from the mid 1980s to the first decade of the twenty first century (López-García, 2015; Skliris et al., 2012; Nikjaer, 2009).

At the end of the twentieth century, some dramatic changes affected the formation of water masses, as well as the salt and heat content of the Eastern and Western Mediterranean basins. At some moment between 1987 and 1995, the area of deep water formation in the EMED shifted from the Adriatic to the Aegean Sea (Roether et al., 1996; 2007). This extraordinary phenomenon is known as the Eastern Mediterranean Transient (EMT). The effects of the EMT could have been transmitted to the WMED as saltier and warmer intermediate waters would have been advected through the Sicily Channel (Gasparini et al., 2005). This could be one of the causes for the formation of a new warmer and saltier WMDW that would have occupied the bottom layer of the WMED, uplifting the "old" WMDW. This phenomenon is named as the Western Mediterranean Transition (WMT, Schroeder et al., 2016; 2010; Zunino et al., 2012; Smith et al., 2008; López-Jurado et al., 2005). It is not yet clear the way in which these transients could affect the observed long term changes as they would be responsible for a redistribution of heat and salt along the water column.

Table I summarizes the main trends for temperature, salinity and density along the twentieth century, indicating the geographical area, the depth level and the time period of each calculation (confidence intervals are included when available in the original work). This table is updated and completed from the one in Vargas-Yáñez et al. (2009). These authors found that some of the discrepancies in trend estimations could be due to the data scarcity, which would make the calculations very sensitive to small changes in the analysis method applied (Vargas-Yáñez et al., 2012), the geographical area selected, the time period analyzed or the way in which the water masses or layers were defined. More recently Llasses et al. (2015) and Jordá and Gomis (2013) have stressed that the present oceanographic data bases are not suitable for describing the climatic 
Ocean Sci. Discuss., https://doi.org/10.5194/os-2017-50

Manuscript under review for journal Ocean Sci.

Discussion started: 16 August 2017

(c) Author(s) 2017. CC BY 4.0 License.

variability for the different depth levels and regions within the Mediterranean Sea. Instead of such a detailed description, Lasses et al. (2015) analyze the salt and heat content for the whole Mediterranean basin concluding that the Mediterranean mean temperature and salinity had increased at rates of $1.01^{\circ} \mathrm{C} / 100 \mathrm{yr}$ and $0.33 \mathrm{psu} / 100 \mathrm{yr}$. Jordá and Gomis (2013) calculate the steric, thermosteric and halosteric level in the Mediterranean Sea using four different data bases. Once again the discrepancies between the results obtained are attributed to the data scarcity, the interpolation method or even the data quality control. Beuvier et al. (2010) modeled the temperature and salinity fields in the Mediterranean Sea from 1960 to 2000. The observed salinity long term changes were well reproduced, nevertheless, the inter-annual variability was lower than the one observed in Rixen et al. (2005). These authors attributed this lack of agreement to the data scarcity.

Not only the results concerning temperature and salinity trends in the Mediterranean Sea show some discrepancies, neither the causes for such changes along the twentieth century are clear. A first hypothesis considers that the warming of the Mediterranean Deep waters is caused by a decrease in the heat losses through the sea surface. This reduction would be linked to global warming (Bethoux et al., 1990). A second hypothesis considers that the warming of the deep waters would be caused by the salinity increase of the LIW which is one of the water masses contributing to WMDW formation (the other one being the AW). According to Rohling and Bryden (1992), the salinity increase of the LIW would be related to the decrease of the freshwater contributions because of the damming of the river Nile and those rivers draining into the Black Sea. This hypothesis considers that saltier waters would not need to cool as much as previously to reach the deep water density and produce deep convection. A third hypothesis also considers that the warming of the deep waters is caused by the salinity increase of the waters contributing to the deep water formation, but in this case, the responsible would be the AW. According to Painter and Tsimplis (2003), Karhmann and Schott (1998), the AW would have become saltier during the second half of the twentieth century because of the river Ebro damming and a reduction of the rainfalls associated to a positive phase of the NAO index from 1960 to mid 1990s. Millot (2007) also considers the AW salinity increase as the cause of the warming of deep Mediterranean waters. Nevertheless, in this case the reason for such a positive trend would be imported from the Atlantic Ocean. This author, after considering the works by Reverdin et al. (2007) and Boyer et al. (2005) argues that the AW has increased its salinity during the second half of the twentieth century and these saltier waters would have flowed into the Mediterranean Sea through the Strait of Gibraltar, contributing finally to the deep water formation.

The present work analyzes temperature and salinity data from the MEDAR/MEDATLAS data base (MEDAR Group, 2002). The main objective is to evaluate the changes in the salt and heat content for the whole Mediterranean basin (MED) during the $20^{\text {th }}$ century. In order to check the effect of the transients on the total heat and salt content of the WMED, long term trends are extended to 2015 using temperature and salinity data from the RADMED monitoring program around the Spanish Mediterranean waters (Tel et al., 2016; López-Jurado et al., 2015). A simple box model considering heat and salt conservation laws, is used to check the already proposed hypotheses concerning the increase in heat and salt content for the Mediterranean basin.

\section{Data and Methods.}

\subsection{Data Analysis}

110 The Mediterranean Sea (MED) was divided into eleven geographical regions (Fig. 1), seven of them corresponding to the WMED and four more regions to the EMED. All the available temperature and salinity profiles from the MEDAR data base were selected for each of these regions from 1943 to 2000. Each individual profile was linearly interpolated into 23 pressure levels $(0,10,20,30,50,100,150,200,300,400,500,600,700,800,900,1000,1200,1400,1500,1750,2000,2250,2500$ dbar). For each region, all the profiles corresponding to the same month and year were averaged. In this way, 23 monthly temperature and salinity time series (one for each isobaric level) were obtained for each region. Potential temperature and 
Ocean Sci. Discuss., https://doi.org/10.5194/os-2017-50

Manuscript under review for journal Ocean Sci.

Discussion started: 16 August 2017

(c) Author(s) 2017. CC BY 4.0 License.

potential density profiles were calculated from temperature, salinity and pressure data. Hereafter potential temperature will always be used. All the profiles corresponding to the same year and season of the year were averaged in order to build seasonal time series. Finally, the four seasonal profiles per year were averaged to obtain annual time series.

In order to obtain time series representing the heat and salt content for both the WMED and EMED basins and for the whole Mediterranean Sea (MED), all the annual temperature and salinity profiles for the seven regions within the WMED and the four regions within the EMED were spatially averaged. The calculation of mean values for each isobaric level and for each region (WMED, EMED or MED) were volume weighted. Temperature and salinity time series for MED were obtained averaging the WMED and EMED ones. Once again these calculations were weighted by the volume of each basin and depth level.

Time series of potential temperature and salinity profiles for each basin (WMED and EMED) were averaged to obtain a mean or climatological profile (Fig. 2a, 2b). These profiles could be considered as representative of the mean or stationary state for each basin. The salinity minimum and maximum were determined for both the WMED and EMED climatological profiles. The mean value was associated to the Atlantic-Mediterranean interface. Those waters above the interface were considered as Atlantic Waters (AW), and those waters below the interface were considered as Mediterranean Waters (MW).

For each year from 1943 to 2000 and for both the WMED and EMED, the position of the salinity interface was determined within each annual salinity profile. Waters above and below such interface level were averaged in order to obtain the annual temperature and salinity for AW and MW. Time series of annual AW and MW temperature and salinity were also estimated for the whole basin (MED) averaging the values from WMED and EMED. The heat content for each layer and basin and for the whole Mediterranean Sea was also estimated as absorbed heat with respect to the climatological profile.

Confidence intervals were estimated for the mean values for the interface depth and salinity and for the temperature and salinity of Atlantic and Mediterranean waters above and below the interface. For such calculation a t-student distribution was assumed for the mean and the confidence interval was obtained according to the classical expression $t_{\alpha / 2, n-1} \frac{s}{\sqrt{n}}$ being $\mathrm{t}_{\alpha / 2, \mathrm{n}-1}$ the $\alpha / 2$ quantile for a t-student distribution with $\mathrm{n}-1$ degrees of freedom, $n$ is the number of data points, $\alpha$ is the significance level which in the present work will be considered as 0.05 (95\% confidence level). $s$ is the estimated standard deviation (Zar, 1984).

\subsection{RADMED data.}

Although the main objective of the present work was to evaluate the different hypotheses concerning the causes of the Mediterranean water warming during the twentieth century, a second objective was to check the impact of the transients on the long term trends of the Mediterranean waters. In the case of the WMED, temperature and salinity data from the RADMED project were available. This project is focused on the multidisciplinary monitoring of continental shelf and slope and deep waters surrounding the Spanish Mediterranean. CTD profiles at fixed stations are obtained four times per year (see López-Jurado et al., 2015 for details). Temperature and salinity time series for Atlantic and Mediterranean waters were obtained from RADMED stations using the same methodology described above for the MEDAR data. RADMED stations are located within the four westernmost boxes in Fig. 1. These time series extend from 1992 to 2015 and were merged with the MEDAR data obtained in the same boxes in order to extend these series from 1943 to 2015 (Vargas-Yáñez et al., 2010). As the RADMED/MEDAR time series did not cover the whole WMED, linear trends and correlation coefficients were calculated using the RADMED/MEDAR series and the MEDAR ones extended to the whole Mediterranean Sea. For this purpose, only the common period of time (1943-2000) was used. 
Ocean Sci. Discuss., https://doi.org/10.5194/os-2017-50

Manuscript under review for journal Ocean Sci.

Discussion started: 16 August 2017

(c) Author(s) 2017. CC BY 4.0 License.

Linear trends were estimated for temperature, salinity and heat content time series constructed from MEDAR and RADMED data. A strait line was fitted by means of least square. The slope of the fit is considered as the average rate of change.

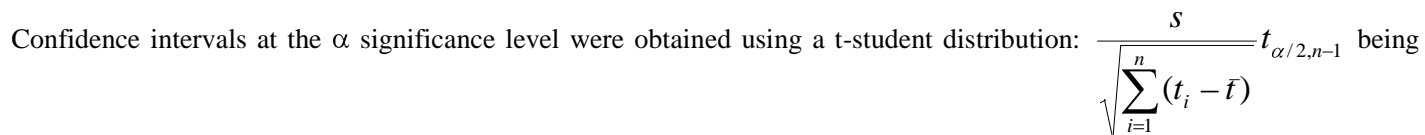
once again $s$ the estimated standard deviation and $t_{i}$ time in years. The lost of degrees of freedom caused by the autocorrelation of the residuals was considered (Vargas-Yáñez et al., 2005; Chelton, 1983).

\subsection{Heat and salt conservation: A box model.}

Previous works have already used box-models for analyzing in a simple way the main features of the Mediterranean Sea (Bethoux, 1979), the changes occurred during the twentieth century (Bethoux and Gentili, 1996; Bethoux et al., 1999) and their effects on the Mediterranean waters flowing into the Atlantic Ocean (Lozier and Sindlinger, 2009).

Some of these models attempted to explain the main features of the Mediterranean waters and the water volumes exchanged through the Strait of Gibraltar. In some cases it was assumed that the Mediterranean Sea was in a steady state and the salt, volume and heat fluxes through the Strait of Gibraltar, sea surface and rivers were balanced (Bethoux, 1979). In these early works, the Mediterranean outflow was considered proportional to the square root of the reduced gravity and therefore to the squared root of the density difference between the Atlantic and Mediterranean waters. A first attempt to model the Mediterranean outflow considered potential and kinetic energy conservation laws and the Strait geometry (Kullenberg, 1953). Bethoux (1979) considered the use of the expression obtained by Whitehead et al. (1974) including the effect of rotation. Lozier and Sindlinger (2009) used a box model to study the evolution of the Mediterranean outflow salinity. In this case the volume of Mediterranean waters flowing through the Strait of Gibraltar followed the maximal exchange model by Bryden and Kinder (1991).

Figure 3 describes schematically the box model used in the present work. Atlantic waters flow into the Mediterranean Sea to compensate for the Mediterranean outflow and the net evaporation, which accounts for the difference between evaporation and precipitation, river runoff and net transport through the Bosphorus and Dardanelles. The Mediterranean outflow was modeled following Lozier and Sindlinger (2009) and Bryden and Kinder (1991). In this box model, $E_{N}$ denotes the net evaporation and $V_{a}, V_{m}$ de Atlantic and Mediterranean flows:

$V_{a}=V_{m}+E_{N}$

$V_{m}=0.141\left(g^{\prime} D_{s}\right)^{1 / 2} \frac{W_{S} D_{S}}{2}$

180 being $D_{S}$ the sill depth $(284 \mathrm{~m}), \frac{W_{S} D_{S}}{2}$ the cross sectional area at the sill $\left(3.16 \times 10^{6} \mathrm{~m}^{2}\right)$ and $g^{\prime}=g \frac{\Delta \rho}{\rho_{m}}$ the reduced gravity.

After one year, the thickness, temperature and salinity of the Atlantic layer is changed by the effect of heat fluxes through the sea surface $(Q)$ and net evaporation:

$$
\frac{d h_{a}}{d t}=-\frac{E_{N}}{A} \quad \frac{d T_{a}}{d t}=\frac{Q}{\rho_{a} c_{P} h_{a}} \quad \frac{d S_{a}}{d t}=-\frac{S_{a}}{h_{a}} \frac{d h_{a}}{d t}
$$


Ocean Sci. Discuss., https://doi.org/10.5194/os-2017-50

Manuscript under review for journal Ocean Sci.

Discussion started: 16 August 2017

(c) Author(s) 2017. CC BY 4.0 License.

The AW becomes cooler and saltier by the effect of surface fluxes, sinks and mixes with the Mediterranean waters which would alter its temperature, salinity and density according to expressions:

$$
T_{m}^{\prime}=\frac{h_{a} T_{a}^{\prime}+h_{m} T_{m}^{\prime}}{h_{a}+h_{m}} \quad S_{m}^{\prime}=\frac{h_{a} S_{a}^{\prime}+h_{m} S_{m}^{\prime}}{h_{a}+h_{m}}
$$

Being $T_{a}^{\prime}, S_{a}^{\prime}, T_{m}^{\prime}, S_{m}^{\prime}$ the temperature and salinity of Atlantic and Mediterranean waters after being modified by surface fluxes and mixing.

\subsection{Initialization of the model and meteorological forcing.}

Initially the Mediterranean Sea is filled with AW. Temperature and salinity profiles from the MEDAR data base were selected from a box located west of the Strait of Gibraltar (Fig. 1). Considering the sill depth, temperature and salinity data for the upper $300 \mathrm{~m}$ were averaged to obtain the temperature and salinity of the inflowing AW. The resulting values were $16.4 \pm 0.3^{\circ} \mathrm{C}$ and $36.3 \pm 0.1 \mathrm{psu}$.

A large range of values can be found in the literature for both the net evaporation and the net heat loss in the Mediterranean Sea. An extensive review of the existing literature revealed that estimations for heat fluxes can differ from $-7 \mathrm{~W} / \mathrm{m}^{2}$ (loss to the atmosphere) to a net gain of $1 \mathrm{~W} / \mathrm{m}^{2}$ (see Criado-Aldeanueva et al., 2012; Ruiz et al., 2008 for some of these values). Precipitation, evaporation and river runoff estimations also change in a wide range: 825 to $1335 \mathrm{~km}^{3} / \mathrm{yr}$ for precipitation, 2320 to $5194 \mathrm{~km}^{3} / \mathrm{yr}$ for evaporation and 230 to $900 \mathrm{~km}^{3} / \mathrm{yr}$ for river runoff (Criado-Aldeanueva et al., 2012; Ludwig et al., 2009; Struglia et al., 2004; Boutkir and Barnier, 2000). Different values have also been obtained for the net flux through the Dardanelles Strait. These values range from 200 to $300 \mathrm{~km}^{3} / \mathrm{yr}$ (Tixeront, 1970; Lacombe et al., 1981; Ozsoy and Ünlüata, 1997). Therefore, considering the lower and upper limits of all these estimations, the net evaporation could be between 1065 and $2659 \mathrm{~km}^{3} / \mathrm{yr}$, which is equivalent to $0.43 \mathrm{~m} / \mathrm{yr}$ to $1.06 \mathrm{~m} / \mathrm{yr}$.

Because of the large uncertainty in the freshwater and heat fluxes, the following approach was adopted. $Q$ and $E_{N}$ in the model were considered as adjusted parameters. The time evolution of the MW properties should reproduce those observed in the MEDAR data base. As explained previously, a mean temperature and salinity profile was obtained for the Mediterranean Sea. Considering waters below the interface, the mean temperature and salinity values for the Mediterranean Waters were determined as $13.45 \pm 0.03{ }^{\circ} \mathrm{C}$ and $38.63 \pm 0.01$ psu respectively. The $Q$ and $E_{N}$ values in the box model were adjusted in such a way that this simple model was able to reproduce the observed Mediterranean properties. In order to accept the validity of this adjustment, the heat flux and net evaporation obtained in this way should relay within the already observed ranges.

\subsection{Sensitivity test.}

To check the dependence of our results on the method used to estimate the volumes of water exchanged through the Strait of Gibraltar, three different approaches were followed. The first one, already commented, was to assume the maximal exchange model proposed by Bryden and Kinder (1991) already used in the box model by Lozier and Sindlinger (2009). The second one was to use the expression proposed by Whitehead et al. (1974) considering the geometry of the Strait and the effect of 
Ocean Sci. Discuss., https://doi.org/10.5194/os-2017-50

Manuscript under review for journal Ocean Sci.

Discussion started: 16 August 2017

(c) Author(s) 2017. CC BY 4.0 License.

Method 1. $\quad V_{m}=0.141\left(g^{\prime} D_{s}\right)^{1 / 2} \frac{W_{S} D_{S}}{2}$

Method 2. $\quad V_{m}=0.5 \sqrt{g^{\prime}} H^{3 / 2} L\left[1-\frac{L^{2}}{3 x_{0}^{2}}\right]$

Method 3. $V_{m}=k\left(\rho_{m}-\rho_{a}\right)$

In the case of method 3, the heat flux, net evaporation and $k$ coefficient were adjusted parameters. Those values reproducing the observed Mediterranean temperature and salinity were considered as the right ones.

\section{Results.}

\subsection{Temperature, salinity and heat content time series.}

The climatiological profiles in Fig. 2 showed an interface at $109 \pm 6$ dbar with a salinity of $38.05 \pm 0.03$ psu in the WMED.

The average potential temperature and salinity for AW within the WMED were $15.41 \pm 0.29^{\circ} \mathrm{C}, 37.81 \pm 0.03$ psu, while the values corresponding to the MW were $12.98 \pm 0.02{ }^{\circ} \mathrm{C}, 38.45 \pm 0.01 \mathrm{psu}$. In the EMED, the interface was located at $49 \pm 10$ dbar with a salinity value of $38.68 \pm 0.03 \mathrm{psu}$. Potential temperature and salinity mean values for the $\mathrm{AW}$ above the interface are $18.83 \pm 0.63{ }^{\circ} \mathrm{C}, 38.58 \pm 0.02 \mathrm{psu}$, and values corresponding to the MW below the interface were $13.87 \pm 0.04{ }^{\circ} \mathrm{C}, 38.75$ $\pm 0.01 \mathrm{psu}$. When the whole Mediterranean basin was considered, the Mediterranean Water mean temperature and salinity were $13.45 \pm 0.03{ }^{\circ} \mathrm{C}$ and $38.63 \pm 0.01 \mathrm{psu}$.

Figures 4 to 6 show the evolution of temperature, heat content and salinity for the Atlantic and Mediterranean waters for the WMED, EME and MED basin. Table II summarizes the observed trends for the different areas and layers. Figure 4a (black line) shows the evolution of the annual AW temperature in the WMED. As already explained, each year, the AWs are considered as those with salinity lower than the WMED interface salinity. This water mass only exhibited inter-annual and decadal variability but no significant trends were observed. The blue line in Fig. 4a is the MW temperature. These waters are those with salinity values higher than the salinity interface. Grey bars represent the water column heat content. In both cases a significant and positive trend was observed. The values were $0.0024 \pm 0.0014{ }^{\circ} \mathrm{C} / \mathrm{yr}$ and $0.54 \pm 0.33 \mathrm{~W} / \mathrm{m}^{2}$ respectively. Notice that the heat content was expressed in $\mathrm{Jx} 10^{21}$. The obtained trends were in $\mathrm{J} / \mathrm{yr}$. In addition, year was converted into seconds and trends were divided by the WMED surface in order to express the trends as $\mathrm{W} / \mathrm{m}^{2}$. The blue line in figure $4 \mathrm{~b}$ is again the MW temperature for the WMED (using the seven boxes from Fig.1). The red line shows the temperature annual time series from 1943 to 2000 obtained using the area corresponding to RADMED project and including the RADMED profiles (1992 to 2000). Although the RADMED/MEDAR series was warmer than the MEDAR one, the inter-annual variability was similar in both cases. The correlation coefficient between these series was 0.6 and statistically significant (Fig. 4c). More interesting is that the linear trend calculated using the RADMED/MEDAR time series from 1943 to 2000 was $0.0025 \pm 0.0029^{\circ} \mathrm{C} / \mathrm{yr}$. Although this result was not significant at the $95 \%$ confidence level, it was very similar to the $0.0024 \pm 0.0017^{\circ} \mathrm{C} / \mathrm{yr}$ obtained using the MEDAR series for the WMED. When this time series was extended to the 19432015 period, this trend was slightly increased, but with a similar value to the previous ones: $0.0028 \pm 0.0019^{\circ} \mathrm{C} / \mathrm{yr}$.

Figure 5a shows the temperature evolution for the AW (green line) and MW (blue line) and the heat content for the water column (grey bars) in the EMED. The MW temperature increased but not in a statistically significant way. The water column 
Ocean Sci. Discuss., https://doi.org/10.5194/os-2017-50

Manuscript under review for journal Ocean Sci.

Discussion started: 16 August 2017

(c) Author(s) 2017. CC BY 4.0 License.

255 heat content did not have a clear trend. On the contrary, the upper layer temperature decreased in a significant way at a rate of $-0.08 \pm 0.03{ }^{\circ} \mathrm{C} / \mathrm{yr}$. When linear trends were estimated for the whole basin, (MED, Fig. $5 \mathrm{~b}$ ), the AW showed a strong and significant negative trend $\left(-0.04 \pm 0.02^{\circ} \mathrm{C} / \mathrm{yr}\right)$ while the $\mathrm{MW}$ and the water column heat content increased at rates of 0.0020 $\pm 0.0018^{\circ} \mathrm{C} / \mathrm{yr}$ and $0.32 \pm 0.43 \mathrm{~W} / \mathrm{m}^{2}$ respectively.

Concerning the salinity evolution, Fig. 6a shows the annual time series of salinity for the WMED AW and MW (green and blue lines, using MEDAR data and the seven boxes in Fig.1), and the MW salinity using the RADMED/MEDAR data base. The red line is for the 1943-2000 period when both data bases are coincident and the black line is the extension to 2015. The AW salinity showed an inter-annual and decadal variability but no long term changes. The MW salinity showed positive and significant trends in all the cases with an intensification of the trends for the period 2000-2015. When considering the EMED and the MED area the results were similar. The AW showed no salting trends while the MW increased its salinity at rates of $0.00055 \pm 0.00052 \mathrm{psu} / \mathrm{yr}$ and $0.00072 \pm 0.00033 \mathrm{psu} / \mathrm{yr}$ respectively.

\subsection{Box Model.}

Using the maximal exchange at the Strait of Gibraltar (method 1, see section 2) the box model (see Figure 3) was run for 1000 years with a time step of one year. As explained in section 2, the net evaporation and sea surface heat flux were tuned for reproducing the observed temperature and salinity of the Mediterranean waters when the equilibrium or steady state was reached. This steady state was reached after 200 years with values of $13.45{ }^{\circ} \mathrm{C}$ and $38.63 \mathrm{psu}$, which are coincident with those estimated from MEDAR data (Fig. 7a). To achieve such equilibrium state, a heat loss of $5.95 \mathrm{~W} / \mathrm{m}^{2}$ and a net evaporation of $2.34 \times 10^{12} \mathrm{~m}^{3} / \mathrm{yr}$, equivalent to $0.94 \mathrm{~m} / \mathrm{yr}$, were used. The transports through the Strait of Gibraltar were 1.23 and $1.16 \mathrm{~Sv}$ for the Atlantic and Mediterranean flows. These values are within the range frequently reported in the literature. The box model seems to be able to reproduce the mean characteristics of the Mediterranean Sea, nevertheless we question how sensitive is this capability to the choice of the expression used for the calculation of the Mediterranean outflow. Methods two and three considering the work by Whitehead et al. (1974) and an outflow proportional to the density difference were also used. For both methods, the Mediterranean properties and the inflow and outflow stabilized after 200 years. For method 2, the MW properties were $13.44{ }^{\circ} \mathrm{C}$ and 38.63 with Atlantic and Mediterranean flows of 1.1 and $1.03 \mathrm{~Sv}$. These steady state values were obtained for a surface heat loss and net evaporation of $5.33 \mathrm{~W} / \mathrm{m}^{2}$ and $2.095 \times 10^{12} \mathrm{~m}^{3} / \mathrm{yr}$ (equivalent to $0.84 \mathrm{~m} / \mathrm{yr}$ ). In the case of method 3, where the Mediterranean outflow was modeled as $k \Delta \rho$, the temperature and salinity for the MW were $13.44^{\circ} \mathrm{C}$ and $38.63 \mathrm{psu}$ and the flows at Gibraltar 1.06 and $1 \mathrm{~Sv}$. The equilibrium state was reached for a heat flux of $5.12 \mathrm{~W} / \mathrm{m}^{2}$ and a net evaporation of $2.01 \times 10^{12} \mathrm{~m}^{3} / \mathrm{yr}(0.8 \mathrm{~m} / \mathrm{yr})$. The proportionality constant $k$ was also selected in order to reproduce reasonable results and the final value was $0.4 \times 10^{6}$. Therefore we can conclude that the box model is not sensitive to the choice of the Mediterranean outflow parameterization. The model reproduces reasonably well the mean values of the Mediterranean waters for a net evaporation ranging from 0.8 to $0.94 \mathrm{~m} / \mathrm{yr}$ and a net heat loss ranging from 5.12 to $5.95 \mathrm{~W} / \mathrm{m}^{2}$.

Once accepted that the results were not sensitive to the parameterization of the Mediterranean outflow, the different hypotheses concerning the changes in the Mediterranean Sea were checked using the method 1 (maximal exchange). After reaching the initial steady state (year 1000), and simulating an abrupt increase in the fresh water deficit (damming of rivers draining into the Eastern or Western basin), the net evaporation was increased, first by $10 \%$ and then by $20 \%$. In both cases the surface heat loss was kept constant at the initial value $5.95 \mathrm{~W} / \mathrm{m}^{2}$. The box model was run for other 1000 years to reach a new equilibrium state. Figure 7 a shows the temperature and salinity increase associated to the $10 \%$ net evaporation increase. Figure $7 \mathrm{~b}$ is a zoom for the initial 300 years after the net evaporation change. Linear trends were calculated for the first 50 years, for comparison with those trends estimated in section 3.1 for the second half of the twentieth century (black dot lines in Fig. 7b). These trends were $0.0017 \mathrm{psu} / \mathrm{yr}$ for salinity and $0.0003{ }^{\circ} \mathrm{C} / \mathrm{yr}$ for temperature. Notice that the salinity trend is 
Ocean Sci. Discuss., https://doi.org/10.5194/os-2017-50

Manuscript under review for journal Ocean Sci.

Discussion started: 16 August 2017

(c) Author(s) 2017. CC BY 4.0 License.

similar to the observed ones, while the temperature trend is an order of magnitude lower. A similar result was obtained when the net evaporation was increased a $20 \%$. In this case, the salinity trend for the first 50 years after the net evaporation increase was $0.0033 \mathrm{psu} / \mathrm{yr}$, while the temperature trend was $0.00058^{\circ} \mathrm{C} / \mathrm{yr}$.

As the increase of the fresh water deficit was not enough to reproduce the observed warming, a new experiment combined an increase by $7 \%$ for the net evaporation with a decrease of $0.4 \mathrm{~W} / \mathrm{m}^{2}$ for the heat losses from the sea to atmosphere. Therefore the new heat loss was $5.5 \mathrm{~W} / \mathrm{m}^{2}$. Figure 8 a shows the stabilization period and the temperature and salinity change after the new surface fluxes were imposed. Figure $8 \mathrm{~b}$ is a zoom for the first 300 years. Once again, linear trends were included for the initial 50 year period. These new trends were $0.0012 \mathrm{psu} / \mathrm{yr}$ for the salinity and $0.0017{ }^{\circ} \mathrm{C} / \mathrm{yr}$ for the temperature. Slight variations for the net evaporation (from 6\% to 7\%) and for the decrease in the heat loss (from 0.4 to 0.46 $\mathrm{W} / \mathrm{m}^{2}$ ) produced similar results with temperature trends ranging from 0.0017 to $0.0019^{\circ} \mathrm{C} / \mathrm{yr}$ and salinity trends from 0.001 to $0.0012 \mathrm{psu} / \mathrm{yr}$.

Finally, the hypothesis of a salting of the upper layer imported from the Atlantic and the consequent warming of the deep waters was checked. After the model was stabilized at the observed temperature and salinity values of the Mediterranean waters, a salinity linear trend was imposed to the temperature of the incoming Atlantic waters. Following Millot (2007) and the works referenced there (Reverdin et al., 2007), linear trends of $0.001 \mathrm{psu} / \mathrm{yr}$ and $0.004 \mathrm{psu} / \mathrm{yr}$ were used. Figure $9 \mathrm{a}$ shows the temperature and salinity changes once the salinity of the incoming AW is linearly increased at a rate of $0.004 \mathrm{psu} / \mathrm{yr}$. The zoom in Fig. 9b shows the evolution for the temperature and salinity of the Mediterranean waters during the first 200 years. Initially the trend for the MW salinity was $0.0009 \mathrm{psu} / \mathrm{yr}$ and that for the temperature was close to zero. For the 50 year period initiated 75 years after the beginning of the AW change, the trends for MW salinity and temperature were 0.0009 $\mathrm{psu} / \mathrm{yr}$ and $5.1 \times 10^{-5} \mathrm{C} / \mathrm{yr}$, respectively. Although the linear trend for the salinity was similar to those observed in historical data, the temperature trend was very low.

\section{Discussion and conclusions.}

The analysis of previous works shows that the deep waters of the Mediterranean Sea have increased its temperature and salinity during the second half of the twentieth century, both in the Western and Eastern Mediterranean. Comparing the different results in table I, the warming trends ranged from the $0.001^{\circ} \mathrm{C} / \mathrm{yr}$ estimated by Lacombe et al. (1985) to the 0.004 ${ }^{\circ} \mathrm{C} / \mathrm{yr}$ obtained by Bethoux et al. (1990). Many different values between these two estimations can be found in the literature. A first reason for these discrepancies is the different periods of time and geographical areas analyzed in each work. Beside this, the data scarcity makes the data analysis very sensitive to the methodology used (Llasses et al., 2015). These authors consider that the present observation systems are suitable for assessing the time evolution of the basin average temperature and salinity but not for specific depth levels. Rixen et al. (2005) provide only qualitative results when temperature and salinity data were considered separately for the WMED and EMED as well as for the Atlantic Water (0-150m), Levantine Intermediate Water (150-600m) and Deep Waters (600m-bottom). According to Rixen et al. (2005) the basin average temperature increased at a rate of $0.0019^{\circ} \mathrm{C} / \mathrm{yr}$. This value is in the range $0.001{ }^{\circ} \mathrm{C}-0.004{ }^{\circ} \mathrm{C}$ obtained from the comparison of works in table I. In fact, if the qualitative analysis by Rixen et al. (2005) is considered, the trends estimated for the whole basin should be associated mainly to the warming of the deep waters.

The analysis of MEDAR data in the present work confirms the warming of deep waters at similar rates to those already reported (table II). These trends for the WMED, EMED and for the whole Mediterranean basin are $0.0024 \pm 0.0014{ }^{\circ} \mathrm{C} / \mathrm{yr}$, $0.0018 \pm 0.0025{ }^{\circ} \mathrm{C} / \mathrm{yr}$ and $0.0020 \pm 0.0018{ }^{\circ} \mathrm{C} / \mathrm{yr}$, respectively, once again coinciding with the known results. In the particular case of the WMED, temperature and salinity data from a monitoring program around the Spanish Mediterranean waters (RADMED) has allowed us to extend previous calculations up to 2015. During the extended period (1943-2015), the 
Ocean Sci. Discuss., https://doi.org/10.5194/os-2017-50

Manuscript under review for journal Ocean Sci.

Discussion started: 16 August 2017

(c) Author(s) 2017. CC BY 4.0 License.

Mediterranean waters have increased the warming trend to $0.0028 \pm 0.0019^{\circ} \mathrm{C} / \mathrm{yr}$. It is not possible to know whether this change is caused by the decadal variability existing in temperature time series, or if this is the result of the Western Mediterranean Transition, with warmer and saltier intermediate waters flowing into the Western Mediterranean, being this heat also transmitted to the deep layers by means of the deep water formation process. In our opinion, the clarification of this point requires 3D circulation models specifically devoted to the study of this process (Herrmann et al., 2008; 2010; Waldman et al., 2017).

The salinity trends estimated for the deep waters range from the $0.0005 \mathrm{psu} / \mathrm{yr}$ estimated by Lacombe et al. (1985) to the $0.0019 \mathrm{psu} / \mathrm{yr}$ obtained by Leaman and Schott (1991), with most of the values found in the literature close or lower than $0.001 \mathrm{psu} / \mathrm{yr}$. The mean salinity for the Mediterranean basin increased at a rate of $0.00075 \mathrm{psu} / \mathrm{yr}$ (Rixen et al., 2005). According to figure 2 in Rixen et al. (2005) and the qualitative analysis therein, the salinity trend for the basin average salinity is caused by both the salinity increase of the intermediate and deep waters in the Western and Eastern Mediterranean. The results in the present work (table II) agree with previous results and the salinity trends for the WMED, EMED and MED were $0.0009 \pm 0.0004 \mathrm{psu} / \mathrm{yr}, 0.00055 \pm 0.00052 \mathrm{psu} / \mathrm{yr}$ and $0.0007 \pm 0.0003 \mathrm{psu} / \mathrm{yr}$ respectively. When these time series were extended up to 2015 within the RADMED area in the Spanish Mediterranean, the new trend was $0.00052 \pm 0.0026$ $\mathrm{psu} / \mathrm{yr}$, lower than the previous ones. If changes in the WMED during the first decade of the twenty first century were associated to the Western Mediterranean Transient, warmer and saltier waters imported from the EMED should increase both the temperature and salinity of the Mediterranean waters. In this case the salinity trend has decreased. It has to be taken into account that the trends estimated until 2000 and those from series extended up to 2015, are not different if the confidence intervals are considered. Therefore, the differences could only be the result of the uncertainty inherent to the inter-annual variability, of the different areas covered by the two series, or simply a result of data scarcity. As in the case of the temperature, modeling experiments oriented to the solution of this question are needed (Herrmann et al., 2008; 2010; Waldman et al., 2017; Beuvier et al., 2010).

Concerning the upper layer, no significant trends could be estimated for the WMED and the MED region. The temperature of the Atlantic Waters in the EMED showed a significant decreasing trend which would be in contradiction with recent works which analyze satellite SST time series (López-García, 2015; Skliris et al., 2012; Nikjaer, 2009). The lack of significant trends for the temperature of the WMED would also be in contradiction with the study by Salat and Pascual (2006). As already stated in the introduction, these discrepancies could be caused by the limited available information from routine monitoring programs and the consequent data scarcity. Linear trends are usually estimated adjusting a straight line to the data by means of least square fits. Confidence intervals depend on the length of the time series and the variance of the residuals or deviations from the linearity. The variance of the time series is linked to inter-annual and decadal variability. The larger the variance, the longer should be the time series in order to detect long term trends in a statistically significant way. Annual time series are obtained averaging data within a geographical region and for a depth range. This process reduces the inter-annual variability when such regions are well sampled and temperature and salinity data are available for all the seasons of the year and for the whole region. Nevertheless, when data are scarce, the averaging process is carried out with very few data. The residual variance is not reduced and the results are very sensitive to the length of the time series or the inclusion or exclusion of data points at the beginning or the end of such series. This could be the case for the AW which is subject to a strong variability. Mediterranean Waters are more homogeneous and the inter-annual and decadal variability, although existing, is much lower, making current time series suitable for trend detection.

Therefore, if Mediterranean Waters are considered, it can be established that the basin average temperature of the Mediterranean Sea has increased during the second half of the twentieth century at a rate around $0.002{ }^{\circ} \mathrm{C} / \mathrm{yr}$. The salinity 
Ocean Sci. Discuss., https://doi.org/10.5194/os-2017-50

Manuscript under review for journal Ocean Sci.

Discussion started: 16 August 2017

(c) Author(s) 2017. CC BY 4.0 License.

trend was around $0.001 \mathrm{psu} / \mathrm{yr}$. It is interesting to notice that the temperature increase in the Mediterranean Waters is equivalent to heat absorption through the sea surface of $0.43 \mathrm{~W} / \mathrm{m}^{2}$ (table II), which is very close to the value reported by Levitus et al. (2012) for the upper $2000 \mathrm{~m}$ of the water column in the world ocean. It is also worth noticing that the changes reported since the beginning of the twentieth century have evidenced an acceleration of the warming trends for the second half of the twentieth century (Rohling and Bryden, 1992; Vargas-Yáñez et al., 2010). The increase of the temperature trends for the WMED series extended to 2015 could simply reflect this acceleration process which is very likely to continue during the twenty first century according to numerical projections (Llasses et al., 2015; Somot et al., 2006).

Several hypotheses have attempted to explain the observed changes. One of them considers that the warming of deep waters is due to the heat absorbed by the sea through the sea-atmosphere interface. Considering that the heat balance of the Mediterranean Sea requires a heat loss through its surface, the warming would be caused by a reduction of such losses. The other hypotheses are based on the salinity increase of surface waters. Surface waters take part in deep convection during extreme winter heat losses, reaching the deep water density. Because of the salinity increase, these waters would not need to cool as much as previously to reach the deep water density. The result would be the formation of warmer deep waters. Some authors have considered that the responsible of the surface water salinity increase was the damming of rivers draining into the EMED, therefore this process would be linked mainly to the Eastern basin. Other authors consider that it has been caused by the river Ebro damming (in the WMED) and the precipitation reduction during a positive phase of the NAO index. In both cases the driving force for the salinity and temperature increase of the Mediterranean waters would be a reduction of the freshwater supply to the Mediterranean Sea, and the consequent increase of the net evaporation. The box model used in this work considers heat, salt and volume conservation laws in a similar way to the conceptual model used by Bethoux et al. (1990) or the box model used by Bethoux et al. (1999) or Lozier and Sindlinger (2009). The model is able to reproduce under steady state conditions the basin average temperature and salinity of Mediterranean waters obtained from MEDAR observations in the present work $\left(13.45^{\circ} \mathrm{C}, 38.63 \mathrm{psu}\right)$. This agreement is achieved when the net evaporation is fixed between 2010 and $2340 \mathrm{~km}^{3} / \mathrm{yr}$ ( 0.8 to $0.94 \mathrm{~m} / \mathrm{yr}$ ) and the heat loss through the sea surface is between 5.12 and $5.95 \mathrm{~W} / \mathrm{m}^{2}$. The uncertainty associated to the model net evaporation and heat loss comes from the different parameterizations used. Nevertheless all these values are in agreement with those found in the literature (Criado-Aldeanueva et al. 2012). The water volumes exchanged at the Strait of Gibraltar for this model steady state are between 1.06 and $1.23 \mathrm{~Sv}$ for the Atlantic inflow and between 0.99 and $1.16 \mathrm{~Sv}$ for the outflow, with a net inflow ranging from 0.06 to $0.07 \mathrm{~Sv}$, once again in a reasonable agreement with observed values (Sánchez-Román et al., 2009). A first experiment considered a 10\% net evaporation increase, producing a salinity linear trend of $0.0017 \mathrm{psu} / \mathrm{yr}$, certainly close to those reported in previous works and in our own analysis. Although the heat loss was kept constant at the value $5.95 \mathrm{~W} / \mathrm{m}^{2}$, the net evaporation increase had the effect of the Mediterranean water warming, as hypothesized by other authors. Nevertheless the obtained trends were $0.0003{ }^{\circ} \mathrm{C} / \mathrm{yr}$ (Fig. 7b), one order of magnitude lower than the observed ones. To be sure that the lack of agreement was not caused by a low estimation of the net evaporation increase, an unrealistic $20 \%$ increment was used. In this case the salinity trend was $0.0033 \mathrm{psu} / \mathrm{yr}$, being higher than the trends estimated in this work and in the literature. On the contrary, the temperature trend was $0.00058{ }^{\circ} \mathrm{C} / \mathrm{yr}$, still lower than the observed ones. Figure $7 \mathrm{c}$ shows the volume transport for the Atlantic inflow and the Mediterranean outflow in the Strait of Gibraltar (blue lines) and the associated heat transports (red lines). Figure $7 \mathrm{~d}$ shows the net volume and heat transport. These figures show the explanation for the warming of the Mediterranean waters based on heat and volume conservation arguments. As the salinity of deep waters increase, their density also increases and so the Mediterranean outflow does. The Atlantic inflow also increases to compensate for the new outflow and net evaporation: $V_{a}=V_{m}+E_{N}$. More relevant for this discussion is that the net transport through Gibraltar must increase, that is, the increment for the inflow must be higher than the increment for the outflow. The net heat transport through the Strait of Gibraltar is $\rho_{a} c V_{a} T_{a}-\rho_{m} c V_{m} T_{m}$. The Atlantic inflow temperature remains constant. Therefore, if the Mediterranean 
Ocean Sci. Discuss., https://doi.org/10.5194/os-2017-50

Manuscript under review for journal Ocean Sci.

Discussion started: 16 August 2017

(c) Author(s) 2017. CC BY 4.0 License.

temperature did not change, the net heat transport through the Strait of Gibraltar would increase and would not be balanced by the sea surface heat loss, which has not been altered. This higher net heat transport would produce the warming of Mediterranean waters until a higher $T_{m}$ produced a new equilibrium state. Beside this explanation for the warming of the Mediterranean waters associated to a higher net evaporation, it has been shown that this process is not able to reproduce the warming trends estimated from the observations.

When both the net evaporation is increased by $7 \%$ and the heat loss to the atmosphere is reduced from $5.95 \mathrm{~W} / \mathrm{m}^{2}$ to 5.55 $\mathrm{W} / \mathrm{m}^{2}$, the linear trends reproduced by the box model for the first 50 years after the change, are $0.0017^{\circ} \mathrm{C} / \mathrm{yr}$ and 0.0012 $\mathrm{psu} / \mathrm{yr}$, very close to the observed values (table II). Slight variations from 6 to a $7 \%$ in the net evaporation increase and from 0.4 to $0.46 \mathrm{~W} / \mathrm{m}^{2}$ also produced reasonable results. It is interesting to notice that the agreement between model results and observations is obtained when the heat losses are close to $0.4 \mathrm{~W} / \mathrm{m}^{2}$, a value very similar to that estimated for the heat absorption rate in the world ocean (Levitus et al., 2012). The hypothesis proposed by Millot (2007) has also been considered. That is, the net evaporation and the heat losses were kept constant and a linear trend was imposed for the salinity of the inflowing Atlantic Waters at Gibraltar. Two experiments with linear trends of $0.001 \mathrm{psu} / \mathrm{yr}$ and $0.004 \mathrm{psu} / \mathrm{yr}$ for the AW were run. In both cases the warming trends for the Mediterranean waters were lower than the observed ones. Figure 9a shows the evolution of the Mediterranean salinity and temperature when a salinity trend for the inflowing AW was imposed. Figure $9 \mathrm{~b}$ is a zoom for the first 200 years after the beginning of the AW salinity trend. Initially the salinity trends for the Mediterranean waters are close to the observed ones, but the temperature trends are close to zero. These trends have been calculated when the model response becomes close to linear and the results are $0.0024 \mathrm{psu} / \mathrm{yr}$ and $0.0004{ }^{\circ} \mathrm{C} / \mathrm{yr}$. Once again the salinity trends are higher than the observed trends, while the warming trends remain much lower than the observed ones.

In summary, data scarcity during the last century makes the detection and quantification of temperature and salinity trends in the Mediterranean Sea a difficult task. Nevertheless it can be established that the basin average temperature and salinity of the Mediterranean Waters have increased along the second half of the twentieth century. These trends would be around 0.002 ${ }^{\circ} \mathrm{C} / \mathrm{yr}$ for the temperature and $0.001 \mathrm{psu} / \mathrm{yr}$ for the salinity. The Mediterranean warming could have been accelerated during the first 15 years of the twenty first century, at least at the Western Mediterranean. According to sea surface time series obtained from satellites and to the results from numerical models, this acceleration could persist or increase along the present century. Considering conservation laws, a simple box model is able to reproduce the main characteristics of the steady state of the Mediterranean Sea: temperature, salinity, heat and freshwater fluxes and transports at the Strait of Gibraltar. This box model shows that the increase of the net evaporation produces both salinity and temperature positive trends for the Mediterranean waters. Nevertheless, the warming trends caused by this increment in the freshwater deficit are lower than the observed ones. The salinity increase of Atlantic waters inflowing through the Strait of Gibraltar also produces a salting and warming of Mediterranean waters, but once again the temperature trends obtained from the model are lower than those estimated from existing data bases. Finally, the changes observed for the Mediterranean waters could only be explained when both an increase of the Mediterranean evaporation (from 6 to 7\%) and a decrease of heat losses (from 0.4 to 0.46 $\mathrm{W} / \mathrm{m}^{2}$ ) are considered. This heat loss decrease is similar to the heat gain observed for the rest of the world ocean. The detection and quantification of changes in the thermohaline properties in specific regions within the Mediterranean and for the different water masses therein requires the maintenance and extension of monitoring programs.

Acknowledgements. The RADMED monitoring programme is funded by the Instituto Español de Oceanografia, and has been partially funded by the DESMMON project (PN I+D+I CTM2008-05695- C02-01), the PERSEUS project (FP7287600), the IRIS-SES project (DG ENV GA-07.0335/2013/659540/SUB/C2.), the ActionMed project (DG-ENV GA11.0661/2015/12631/SUB/ENVC.2 ) ATHAPOC project (PN I+D+I CTM2014-54374-R). Some of the infrastructures 
Ocean Sci. Discuss., https://doi.org/10.5194/os-2017-50

Manuscript under review for journal Ocean Sci.

Discussion started: 16 August 2017

(c) Author(s) 2017. CC BY 4.0 License. Científico-Técnico Para Estudios de Oceanografía Biogeofísica en Baleares" (IEOC13-4E- 1844). Some of the instruments used during the cruises were made available to the RADMED programme by the Balearic Islands Coastal Observing and Forecasting System, SOCIB.

\section{References}

Bethoux, J.P., B. Gentili, P. Morin, E. Nicolas, C. Pierre, D. Ruiz-Pino, 1999. The Mediterranean Sea: a miniature ocean for climatic and environmental studies and a key for the climate functioning of the North Atlantic. Progress in Oceanography 44,131-146.

Bethoux, J.P., B. Gentili, J. Raunet, D. Taillez, 1990. Warming trend in the Wetern Mediterranean deep water. Nature, Vol. $347,660-662$.

Bethoux, J.P., 1979. Budgets of the Mediterranean Sea. Their dependence on the local climate and on the characteristics of the Atlantic waters. Oceanol. Acta, 2, 157-163.

Beuvier, J., F. Sevault, M. Herrmann, H. Kontoyiannis, W. Ludwig, M. Rixen, E. Stanev, K. Bérenger, S. Somot, 2010. Modeling the Mediterranean Sea interannual variability during 1961-2000: Focus on the Eastern Mediterranean Transient. J. Geophys. Res., 115, C08017, doi: 10.1029/2009JC005950.

Boukthir, M., B. Bernier, 2000. Seasonal and inter-annual variations in the surface freshwater flux in the Mediterranean Sea from the ECMWF re-analysis Project. J. Mar. Syst., 24, 343-354.

Boyer, T.P., S. Levitus, J.I. Antonov, R.A. Locarnini, H.E. García, 2005. Linear trends in salinity for the world ocean, 19551998. Geophys. Res. Lett., 32, L01604. Doi: 10.1029/2004GL021791.

Bryden, H.L., T.H. Kinder, 1991. Steady 2-layer exchange through the Strait of Gibraltar. Deep-Sea Res., 38S, 445-463.

Chelton, D.B., 1983. Effects of sampling errors in statistical estimations. Deep Sea Res. Part A, 30, 1083-1103.

Criado-Aldeanueva, F., F.J. Soto-Navarro, J. García-Lafuente, 2012. Seasonal and inteannual variability of surface heat and freshwater fluxes in the Mediterranean Sea: budgets and Exchange through the Strait of Gibraltar. Int. J. Climatol., 32, 286302 .

Gasparini, G.P., A. Ortona, G. Budillon, M. Astraldi, E. Sansone, 2005. The effect of the Eastern Mediterranean Transient on the hydrographic characteristics in the Strait of Sicily and in the Tyrrhenian. Deep-See Res. I, 52, 915-935.

Herrmann, M., F. Sevault, J. Beuvier, S. Somot, 2010. What induced the exceptional 2005 convection event in the northwestern Mediterranean basin? Answers from a modeling study. J. Geophys. Res., Vol. 115, C12051, doi: 10.1029/2010JC006162.

Herrmann, M., C. Estournel, M. Déqué, P. Marsaleix, F. Sevault, S. Somot, 2008. Dense water formation in the Gulf of Lions shelf: Impact of atmospheric interannual variability and climate change. Cont. Shelf Res., 28, 2092-2112.

Jordá, G., D. Gomis, 2013. Reliability of the steric and mass components of the Mediterranean sea level es estimated from hydrographic gridded products. Geophys. Res. Lett., 40, 3655-3660, doi: 10.1002/grl.50718.

Krahmann, G. , F. Schott, 1998. Longterm increases in Western Mediterranean salinities and temperatures: anthropogenic and climatic sources. Geophys. Res. Lett. Vol. 25, No. 22, 4209-4212. 
Ocean Sci. Discuss., https://doi.org/10.5194/os-2017-50

Manuscript under review for journal Ocean Sci.

Discussion started: 16 August 2017

(c) Author(s) 2017. CC BY 4.0 License.

Lacombe, H., P. Tchernia, L. Gamberoni, 1985. Variable bottom water in the Western Mediterranean basin. Prog. Oceanogr., 14, 319-338.

Lacombe, H., J.C. Gascard, J. Gonella, J.P. Bethoux, 1981.Response of the Mediterranean to the water and energy fluxes across its surface, on seasonal and interannual scales. Oceanologica Acta. Vol4, nº2

500 Leaman, K.D., F. Schott, 1991. Hydrographic structure of the convection regime in the Gulf of Lions: Winter 1987. J. Phys. Oceanogr., Vol. 21, 575-598.

Levitus S., J.I. Antonov, T.P. Boyer, O.K. Baranova, H. E. García, R. A. Locarnini, A. V. Mishonov, J. R. Reagan, D. Seidov, E. S. Yarosh, M. M. Zweng, 2012. World ocean heat content and thermosteric sea level change (0-2000 m), $1955-$ 2010. Geophys. Res. Lett., Vol. 39, L10603, doi: 10.1029/2012GL051106.

505 Llasses, J., G. Jordá, D. Gomis, 2015. Skills of different hydrographic networks in capturing changes in the Mediterranean Sea at climate scales. Climate Research, 63, 1-18.

López García, M.J., 2015. Recent warming in the Balearic Sea and Spanish Mediterranean coast. Towards an earlier and longer summer. Atmósfera, 28(3), 149-160.

López-Jurado, J.L., C. González-Pola, P. Vélez-Belchí, 2005. Observation of an abrupt diruption of the long-term warming 510 trend at the Balearic Sea, western Mediterranean Sea, in summer 2005. Geophysical Research Letters, vol 32. Doi: $10.1029 / 2005$ GL024430

López-Jurado, J.L., R. Balbín, B. Amengual, A. Aparicio-González, M.L. Fernández de Puelles, M.C. García-Martínez, M. Gaza, J. Jansá, A. Morillas-Kieffer, F. Moya, R. Santiago, M. Serra, M. Vargas-Yáñez, L. Vicente, 2015. The RADMED monitoring program: towards an ecosystem approach. Ocean Sci. Discuss, 12, 645-671. doi: 10.5194/osd-12-6452015.

Lozier, M. S., Sindlinger, L., 2009. On the source of Mediterranean Overflow water property changes. Journal of Physical Oceanography, vol. 39. Doi: 10.1175/2009JPO4109.1

Ludwig, W., E. Dumont, M. Meybeck, S. Heussner, 2009. River discharges of water and nutrients to the Mediterranean and Black Sea: Major drivers for ecosystem changes during past and future decades. Prog. In Oceanogr., 80, 199-217.

MEDAR Group, 2002 - MEDATLAS/2002 database Mediterranean and Black Sea database of temperature salinity and biochemical parameters. Climatological Atlas.

Millot, C., 2007. Interannual salinification of the Mediterranean inflow. Geophys. Res. Lett., Vol. 34, doi: 10.1029/2007GL031179.

Nykjaer, L. 2009. Mediterranean Sea surface warming 1985-2006. Climate Research. Vol.39, 11-17. Doi: 10.3354/cr00794.

Özsoy, E., Ü.,Ünlüata, 1997. Oceanography of the Black Sea: a review of some recent results. Earth-Science Reviews, 231272.

Painter, S.C., M.N. Tsimplis, 2003. Temperature and salinity trends in the upper waters of the Mediterranean Sea as determined from MEDATLAS data set. Cont. Shelf Res., 23, 1507-1522. 
Ocean Sci. Discuss., https://doi.org/10.5194/os-2017-50

Manuscript under review for journal Ocean Sci.

Discussion started: 16 August 2017

(c) Author(s) 2017. CC BY 4.0 License.

Reverdin, G., E. Kestenare, C. Frankignoul, T. Delcroix, 2007. Surface salinity in the Atlantic Ocean $\left(30^{\circ}\right.$ S $-50^{\circ}$ N). Prog. In Oceanogr., 73, 311-340.

Rixen, M, J-M. Beckers, S. Levitus, J. Antonov, T. Boyer, C. Maillard, M. Fichaut, E. Balopoulos, S. Iona, H. Dooley, M-J. García, B. Manca, A. Giorgetti, G. Manzella, N. Mikkailov, N. Pinardi, M. Zavaterilli, 2005. The western Mediterranean Deep Water: a proxy for climate change. Geophysical Research Letters. Doi:10.1029/2005GL022702.

Roether, W., B. Klein, B. B. Manca, A. Theocharis, S. Kioroglou, 2007. Transient Eastern Mediterranean deep waters in response to massive dense-water output of the Aegean Sea in the 1990s.

Roether, W., B.B. Manca, B. Klein, D. Bregant, D. Georgopoulos, V. Beitzel, V. Kovacevic, A. Luchetta, 1996. Recent changes in the Eastern Mediterranean Deep Waters. Science, Vol. 271, 333-335.

Rohling, E.J., H.L. Bryden, 1992. Man-induced salinity and temperature increase in Western Mediterranean Deep Water. J. Geophys. Res., Vol. 97, No. C7, 11191-11198.

Ruiz, S., D. Gomis, Sotillo, M.G., Josey, S. A., 2008. Characterization of surface heat fluxes in the Mediterranean Sea from

a 44-year hig-resolution atmospheric data set. Global and Planetary Change, 63, 258-274. Doi:10.1016/j.gloplacha.2007.12.002

Salat, J., J. Pascual, 2006. Principales tendencias climatológicas en el Mediterráneo Noroccidental a partir de más de 30 años de observaciones oceanográficas en la costa catalana. En Clima, Sociedad y Medio Ambiente. J.M. Cuadrat Prats, M.A. Sánchez, S.M. Vicente Serrano, S. Lanjeri, N. De Luis Arrillaga, J.C. González-Hidalgo (Editores). Publicaciones de la Asociación Española de Climatología (AEC), serie A, nº 5, 284-290.

Sánchez-Román, A, G. Sannino, J. García-Lafuente, A. Carrillo, F. Criado-Aldeanueva, 2009. Transport estimates at the western section of the Strait of Gibraltar: A combined experimental and numerical modeling study. J. Geophys. Res. Vol., 114, C06002, doi: 10.1029/2008JC005023.

Schroeder, K., J. Chiggiato, H.L. Bryden, M. Borghini, S.B. Ismail, 2016. Abrupt climate shift in the Western Mediterranean Sea. Scientific Reports, 6: 23009, doi:10.1038/srep23009.

Schroeder, K., S.A. Josey, M. Hermann, L. Grignon, G.P. Gasparini, H.L. Bryden, 2010. Abrupt warming and salting of the Western Mediterranean Deep Water after 2005: Atmiospheric forcing and lateral advection. J. Geophys. Res., 115, C08029. Doi: 10.1029/2009JC005749.

Skliris, N., S. S. Sofianos, A. Gkanasos, A. Mantziafou, V. Versatis, P. Axaopoulos, A. Lascaratos, 2012. Decadal scale variability of sea surface temperatura in the Mediterranean Sea in relation to atmospheric variability. Ocean Dynamics, doi: 10.1007/s10236-011-0493-5.

Smith, R.O., H.L. Bryden, K. Stansfield, 2008. Observations of new western Mediterranean deep water formation using Argo floats 2004-2006. Ocean Science, 4, 133-149. www.ocean-sci.net/4/133/2008/

Somot, S., F. Sevault, M. Déqué, 2006. Transient climate change scenario simulation of the Mediterranean Sea for the twenty-first century using a high-resolution ocean circulation model. Clim. Dyn., 27, 851-879, doi: 10.1007/s00382-0060167-z. 
Ocean Sci. Discuss., https://doi.org/10.5194/os-2017-50

Manuscript under review for journal Ocean Sci.

Discussion started: 16 August 2017

(c) Author(s) 2017. CC BY 4.0 License.

Sparnocchia, S., G.M.R. Manzella, P.E. La Violette, 1994. The interanual and seasonal variability of the MAW and LIW core properties in the Western Mediterranean Sea. En Seasonal and Interannual variability of the Western Mediterranean. Coastal and Estuarine Studies. P.E. La Violette (Editor), American Geophysical Union, Washington.

Struglia, M.V., A. Mariotti, A. Filograsso, 2004. River discharge into the Mediterranean Sea: Climatology and aspects of the observed variability. J. Clim., 17, 4740-4751

Tel, E., R. Balbín, J.M. Cabanas, M.J. García, M.C. García-Martínez, C. González-Pola, A. Lavín, J.L. López-Jurado, C. Rodríguez, M. Ruiz-Villareal, R.F. Sánchez-Leal, M. Vargas-Yáñez, P. Vélez-Belchi, 2016. IEOOS: The Spanish Institute of Oceanography Observing System. Ocean Sci. Discuss., 12, 345-353. doi. 10.5194/os-12-345-2016.

Tixeront, J., 1970. Le bilan hydrologique de la Mer Noire et de la Mer Mediterranée. Cah. Océanogr., 22, 227-237.

Vargas-Yáñez, M., E. Mallard, M. Rixen, P. Zunino, M.C. García-Martínez, F. Moya, 2012. The effect of interpolation methods in temperatura and salinity trends in the Western Mediterranean. Medit. Mar. Sci., 13/1, 118-125.

Vargas-Yáñez, M., F. Moya, M.C. García-Martínez, E. Tel, P. Zunino, F. Plaza, J. Salat, J. Pascual, J.L. López-Jurado, M. Serra, 2010. Climate change in the Western Mediterranean Sea 1900-2008. J. Mar. Syst., 82, 171-176.

Vargas-Yáñez, M., F. Moya, E. Tel, M.C. García-Martínez, E. Guerber, M. Bourgeon, 2009. Warming and salting in the Western Mediterranean during the second half of the 20th century: Inconsistencies, unknowns and the effect of data processing. Sci. Mar. 73(1), doi: 10.3989/scimar.2009.73n1007.

Vargas-Yáñez, M., J. Salat, M. L. Fernández de Puelles, J.L. López-Jurado, J. Pascual, T. Ramírez, D. Cortés, I. Franco, 2005. J. Geophys. Res., Vol. 110, C10019, doi: 10.1029/2004JC002799.

Waldman, R., S. Somot, M. Herrmann, A. Bosse, G. Caniaux, C. Estoumel, L. Houpert, L. Prieur, F. Sevault, P. Testor, 2017. Modelling the intense 2012-2013 dense water formation event in the northwestern Mediterranean Sea: Evaluation with an esemble simulation approach. J. Geophys. Res. Oceans, 122, 1297-1324, doi: 10.1002/2016JC012437.

Whitehead, J.A., A. Leetmaa, R.A. Knox, 1974. Rotating hydraulics of strait and sill flows. Geophys. Fluid Dyn., 6, 101 125 .

Zar, J.H., 1984. Biostatistical Analysis, ed 2. Englewood Cliffs, NJ Prentice-Hall, Inc., New Jersey.

Zunino, P., K. Schroeder, M. Vargas-Yáñez, G.P. Gasparini, L. Coppola, M.C. García-Martínez, F. Moya, 2012. Effects of the Western Mediterranean Transition on the resident water masses: Pure warming, pure freshening and pure heaving. J. Mar. Syst., vol. 96-97, 15-23, doi: 10.1016/j.jmarsys.2012.01.011. 
Ocean Sci. Discuss., https://doi.org/10.5194/os-2017-50

Manuscript under review for journal Ocean Sci.

Discussion started: 16 August 2017

Discussions

(c) Author(s) 2017. CC BY 4.0 License.

(c) (1)

\begin{tabular}{|c|c|c|c|c|c|c|}
\hline Author & $\begin{array}{c}\text { Geographical } \\
\text { area }\end{array}$ & Level & Period & $\theta\left({ }^{\circ} \mathrm{C} / \mathrm{yr}\right)$ & $\begin{array}{c}\mathbf{S} \\
\text { (psu/yr) }\end{array}$ & $\begin{array}{c}\sigma_{\theta} \\
\left(\mathrm{Kgm}^{-3} / \mathbf{y r}\right)\end{array}$ \\
\hline $\begin{array}{c}\text { Lacombe et al. } \\
\text { (1985) }\end{array}$ & WMED & $\geq 2000 \mathrm{~m}$ & $1909-1975$ & 0.001 & 0.0002 & \\
\hline Bethoux et al. (1990) & WMED & $\geq 2000 \mathrm{~m}$ & $1959-1989$ & 0.004 & 0.001 & $\mathrm{~N}$ \\
\hline $\begin{array}{c}\text { Leamann \& Schott } \\
\text { (1991) }\end{array}$ & NWMED & $\begin{array}{l}1850 \leq \mathrm{Z} \\
\leq 2050\end{array}$ & $1969-1987$ & 0.0027 & 0.0019 & $\mathrm{~N}$ \\
\hline \multirow[t]{8}{*}{$\begin{array}{c}\text { Rohling \& Bryden } \\
\text { (1992) }\end{array}$} & $\begin{array}{c}\text { Africa- }-42^{\circ} \mathrm{N} \\
0^{\circ}-10^{\circ} \mathrm{E} \\
\end{array}$ & $2000 \mathrm{~m}$ & 1909-1989 & 0.00083 & 0.00069 & 0.00037 \\
\hline & $\begin{array}{c}\text { Africa- } 42^{\circ} \mathrm{N} \\
0^{\circ}-10^{\circ} \mathrm{E} \\
\end{array}$ & $2000 \mathrm{~m}$ & $1955-1989$ & 0.0016 & 0.00095 & 0.00037 \\
\hline & $\begin{array}{l}41^{\circ} \mathrm{N}-42^{\circ} \mathrm{N} \\
5^{\circ} \mathrm{E}-7^{\circ} 50^{\prime} \mathrm{E} \\
\end{array}$ & $\begin{array}{c}\text { Salinity } \\
\text { maximum }\end{array}$ & $1909-1989$ & & 0.00092 & \\
\hline & $\begin{array}{l}41^{\circ} \mathrm{N}-42^{\circ} \mathrm{N} \\
5^{\circ} \mathrm{E}-7^{\circ} 50^{\prime} \mathrm{E}\end{array}$ & $\begin{array}{c}\text { Salinity } \\
\text { maximum }\end{array}$ & $1955-1989$ & & 0.0025 & \\
\hline & $\begin{array}{c}\text { Africa- } 35^{\circ} \mathrm{N} \\
20^{\circ} \mathrm{E}-22^{\circ} 50^{\prime} \mathrm{E}\end{array}$ & $\begin{array}{c}\text { Salinity } \\
\text { maximum }\end{array}$ & $1909-1989$ & & 0.0016 & \\
\hline & $\begin{array}{c}\text { Africa- } 35^{\circ} \mathrm{N} \\
20^{\circ} \mathrm{E}-22^{\circ} 50^{\prime} \mathrm{E}\end{array}$ & $\begin{array}{c}\text { Salinity } \\
\text { maximum }\end{array}$ & $1955-1989$ & & 0.0046 & \\
\hline & $\begin{array}{c}\text { Africa- } 35^{\circ} \mathrm{N} \\
24^{\circ} \mathrm{E}-26^{\circ} 50^{\prime} \mathrm{E}\end{array}$ & $\begin{array}{c}\text { Salinity } \\
\text { maximum }\end{array}$ & $1909-1989$ & & 0.0014 & \\
\hline & $\begin{array}{c}\text { Africa- } 35^{\circ} \mathrm{N} \\
24^{\circ} \mathrm{E}-26^{\circ} 50^{\prime} \mathrm{E} \\
\end{array}$ & $\begin{array}{c}\text { Salinity } \\
\text { maximum }\end{array}$ & $1955-1989$ & & 0.0021 & \\
\hline \multirow{2}{*}{$\begin{array}{c}\text { Sparnocchia et al. } \\
\text { (1994) }\end{array}$} & WMED & AW core & $1950-1987$ & $\mathrm{~N}$ & $\mathrm{~N}$ & \\
\hline & $\begin{array}{l}\text { Sicily, Ligurian } \\
\text { an Balearic Sea }\end{array}$ & LIW core & $1950-1987$ & $\begin{array}{c}0.0081 \pm 0.002 \\
7 \\
\end{array}$ & $0.0016 \pm 0.0005$ & \\
\hline \multirow{2}{*}{$\begin{array}{c}\text { Bethoux \& Gentili } \\
\text { (1996) }\end{array}$} & WMED & $2000 \mathrm{~m}$ & 1959-1994 & 0.0036 & 0.0011 & $\mathrm{~N}$ \\
\hline & South of Nice & $300-400 \mathrm{~m}$ & $1950-1992$ & 0.0068 & 0.0018 & \\
\hline \multirow[t]{5}{*}{$\begin{array}{c}\text { Krahmann \& Schott } \\
\text { (1998) }\end{array}$} & $\begin{array}{c}\text { Africa- } 39^{\circ} \mathrm{N} \\
5^{\circ} \mathrm{W}-10^{\circ} \mathrm{E}\end{array}$ & $0-70 \mathrm{~m}$ & 1960-1995 & $\mathrm{N}$ & $\mathrm{N}$ & \\
\hline & $\begin{array}{c}39^{\circ} \mathrm{N}-44^{\circ} \mathrm{N} \\
0^{\circ}-10^{\circ} \mathrm{E}\end{array}$ & $0-70 \mathrm{~m}$ & $1960-1995$ & $\mathrm{~N}$ & $0.0037 \pm 0.0009$ & \\
\hline & Tyrrhenian Sea & $0-70 \mathrm{~m}$ & $1960-1995$ & $\mathrm{~N}$ & $\mathrm{~N}$ & \\
\hline & $\begin{array}{c}\text { Three regions } \\
\text { above }\end{array}$ & $275-475$ & $1960-1995$ & $\mathrm{~N}$ & $\mathrm{~N}$ & \\
\hline & $\begin{array}{c}39^{\circ} \mathrm{N}-44^{\circ} \mathrm{N} \\
0^{\circ}-10^{\circ} \mathrm{E} \\
\end{array}$ & $1625-2750$ & $1960-1995$ & $\begin{array}{c}0.0016 \pm 0.000 \\
5 \\
\end{array}$ & $0.0008 \pm 0.0001$ & $\mathrm{~N}$ \\
\hline \multirow{4}{*}{$\begin{array}{c}\text { Painter \& Tsimplis } \\
(\text { (2003) }\end{array}$} & WMED & $0-200 \mathrm{~m}$ & $1945-1990$ & $\mathrm{~N}$ & increase & \\
\hline & EMED & $0-200 \mathrm{~m}$ & $1945-1990$ & decrease & increase & \\
\hline & Levantine basin & LIW core & $1945-1990$ & & $\begin{array}{c}- \\
0.0007 \pm 0.0009 *\end{array}$ & \\
\hline & Sicilian basin & LIW core & $1945-1990$ & -0.0010 & $0.0011 \pm 0.0007$ & \\
\hline Rixen et al. (2005) & MED & 0-bottom & $1950-2000$ & $\begin{array}{c}0.0019 \pm 0.000 \\
1\end{array}$ & $\begin{array}{c}0.00075 \pm 0.0000 \\
5 \\
\end{array}$ & \\
\hline $\begin{array}{c}\text { Salat \& Pascual } \\
(2006)\end{array}$ & Catalonian shelf & $0-80 \mathrm{~m}$ & $1974-2005$ & $0.027 \pm 0.007$ & & \\
\hline \multirow[t]{3}{*}{$\begin{array}{c}\text { Vargas-Yáñez et al. } \\
\text { (2010) }\end{array}$} & WMED & $0-200$ & $1943-2000$ & $0.013 \pm 0.012$ & $\begin{array}{c}0.00097 \pm 0.0013 \\
*\end{array}$ & \\
\hline & & $200-600$ & $1943-2000$ & $\begin{array}{c}0.0004 \pm 0.002 \\
*\end{array}$ & $0.0013 \pm 0.00043$ & \\
\hline & & 600-bottom & $1943-2000$ & $0.002 \pm 0.001$ & $0.0009 \pm 0.0004$ & \\
\hline \multirow[t]{2}{*}{ Skliris et al. (2012) } & WMED & surface & $1973-2008$ & 0.022 & & \\
\hline & EMED & surface & $1973-2008$ & 0.026 & & \\
\hline Llasses et al. (2015) & $\begin{array}{l}\text { Numerical } \\
\text { model. MED }\end{array}$ & 0-bottom & $1962-2100$ & $0.011 \pm 0.003$ & $0.0036 \pm 0.0011$ & \\
\hline
\end{tabular}

595 Table I. Linear trends for temperature, salinity and density estimated in different works published from the 1980s to the beginning of the twenty first century. Confidence intervals are included when they were included in the original works. In some cases it was reported that the trends were between two values; in such cases the mean value has been taken and the confidence interval has been expressed as half 
Ocean Sci. Discuss., https://doi.org/10.5194/os-2017-50

Manuscript under review for journal Ocean Sci.

\begin{tabular}{cccc}
\hline & $\begin{array}{c}\text { Temperature } \\
(\mathrm{o} C / \mathrm{yr})\end{array}$ & $\begin{array}{c}\text { Salinity } \\
(\mathbf{p s u} / \mathrm{yr})\end{array}$ & $\begin{array}{c}\text { Heat content } \\
\left(\mathbf{W} / \mathrm{m}^{\mathbf{2}}\right)\end{array}$ \\
\hline WMED-AW & $\mathbf{0 . 0 3 3} \pm \mathbf{0 . 0 1 7}$ & $0.0011 \pm 0.0019$ & $\mathbf{0 . 0 2} \pm \mathbf{0 . 0 1}$ \\
WMED-MW & $\mathbf{0 . 0 0 2 4} \pm \mathbf{0 . 0 0 1 4}$ & $\mathbf{0 . 0 0 0 9} \pm \mathbf{0 . 0 0 0 4}$ & $\mathbf{0 . 5 4} \pm \mathbf{0 . 3 3}$ \\
WMED-water column & $\mathbf{0 . 0 0 3 1 \pm 0 . 0 0 1 7}$ & $\mathbf{0 . 0 0 1} \pm \mathbf{0 . 0 0 0 5}$ & $\mathbf{0 . 5 4} \pm \mathbf{0 . 3 3}$ \\
EMED-AW & $-\mathbf{0 . 0 8 0} \pm \mathbf{0 . 0 3 3}$ & $-0.0011 \pm 0.0013$ & $-\mathbf{0 . 0 5} \pm \mathbf{0 . 0 2}$ \\
EMED-MW & $0.0018 \pm 0.0025$ & $0.00055 \pm 0.00052$ & $0.39 \pm 0.52$ \\
EMED-water column & $-0.0001 \pm 0.0021$ & $\mathbf{0 . 0 0 0 7 8} \pm \mathbf{0 . 0 0 0 5 4}$ & $0.21 \pm 0.58$ \\
MED-AW & $-\mathbf{0 . 0 4 1} \pm \mathbf{0 . 0 2 3}$ & $-0.0007 \pm 0.001$ & $-\mathbf{0 . 0 4 4} \pm \mathbf{0 . 0 2 9}$ \\
MED-MW & $\mathbf{0 . 0 0 2 0} \pm \mathbf{0 . 0 0 1 8}$ & $\mathbf{0 . 0 0 0 7 2} \pm \mathbf{0 . 0 0 0 3 3}$ & $\mathbf{0 . 4 3} \pm \mathbf{0 . 3 8}$ \\
MED-water column & $\mathbf{0 . 0 0 2 0} \pm \mathbf{0 . 0 0 1 4}$ & $\mathbf{0 . 0 0 0 8} \pm \mathbf{0 . 0 0 0 4}$ & $0.32 \pm 0.43$ \\
\hline
\end{tabular}

Table II. Temperature, salinity and heat content linear trends for the Western (WMED) and Eastern Mediterranean (EMED) and for the whole Mediterranean basin (MED). In all the cases, the waters with salinity lower (AW) and higher (MW) than the Atlantic-Mediterranean interface ones have been analyzed. The whole water column from the sea surface to the bottom has also been included (water column). 95 $\%$ confidence intervals are included. Those trends statistically significant at the $95 \%$ confidence levels are in bold.

\section{Figures captions.}

Figure 1. Mediterranean Sea. Temperature and salinity data have been obtained from MEDAR/MEDATLAS in seven boxes in the Western Mediterranean and four boxes in the Eastern Mediterranean. Temperature and salinity data from a box in the Gulf of Cádiz are used for the characterization of Atlantic Waters flowing into the Mediterranean Sea.

Figure 2. Figure 2a shows the climatological or mean temperature and salinity profiles for the Western Mediterranean. The minimum salinity is at the sea surface and the maximum salinity corresponds to the core of the LIW. The mean values from the minimum and maximum provides the position of the Atlantic-Mediterranean interface. Figure $2 b$ is the same for the Eastern Mediterranean.

Figure 3. Schematic of the box model.

Figure 4. Figure 4a shows the Atlantic Water temperature (green line) Mediterranean Water temperature (blue line) and water column heat content (grey bars) for the Western Mediterranean. In all the cases the data source is MEDAR/MEDATLAS. Figure 4b shows again the Mediterranean Water temperature using only MEDAR/MEDATLAS data. Red line shows the temperature for the same period of time (1943-2000) merging RADMED data and MEDAR/MEDATLAS data only from the same geographical areas of RADMED project: Alboran Sea, Cape Palos, Balearic Sea and Gulf of Lions in Fig. 1. Black line is the extension of the merged MEDAR/RADMED time series until 2015. Figure $4 \mathrm{c}$ shows the correlation between the MEDAR/RADMED and the MEDAR time series over the overlapping period of time.

Figure 5. Figure 5a. Green line is the Atlantic Water temperature for the Eastern Mediterranean. Blue line is the Mediterranean Water temperature and grey bars represent the water column heat content. Figure $5 \mathrm{~b}$ is the same for the whole Mediterranean basin.

Figure 6a. Salinity time series for the Atlantic waters (green) and Mediterranean waters (blue) in the Western Mediterranean. Red line is salinity for the joined MEDAR/RADMED time series from 1943 to 2000, and black line is its extension to 2015. Figure 6b. Time series for the Atlantic water (green) and Mediterranean waters (blue) in the Eastern Mediterranean. Figure $6 \mathrm{c}$ is the same for the whole Mediterranean Sea. 
Ocean Sci. Discuss., https://doi.org/10.5194/os-2017-50

Manuscript under review for journal Ocean Sci.

Figure 7. Figure 7a shows the time evolution of temperature (blue) and salinity (red) for the Mediterranean waters in the box model. The maximal exchange equation is used for the Mediterranean outflow parameterization. The box model is run for 1000 years to achieve a steady state. The surface heat flux and the net evaporation are $5.95 \mathrm{~W} / \mathrm{m} 2$ and $0.94 \mathrm{~m} / \mathrm{yr}$. After year 1000, the net evaporation is increased a $10 \%$ while the heat flux remained constant. Figure $7 \mathrm{~b}$ is a zoom for the Mediterranean Water temperature and salinity for the first 300 years after the net evaporation is changed. Linear trends are for to the initial 50 year period. Figure $7 \mathrm{c}$ shows the heat transports through the Strait of Gibraltar. Dashed red line is for the Atlantic Water heat transport and red continuous line for the Mediterranean heat transport. Blue lines show the volume transport, dashed line for the Atlantic water and continuous line for the Mediterranean water. Figure $7 \mathrm{~d}$ shows the net (Atlantic minus Mediterranean) heat (red) and volume transports at Gibraltar.

Figure 8. Figure 8a shows the evolution of the temperature (blue) and salinity (red) for the Mediterranean waters from the box model using the maximal exchange parameterization for the Mediterranean outflow. The first 1000 years show the stabilization for a heat flux of 5.95 $\mathrm{W} / \mathrm{m}^{2}$ and a net evaporation of $0.94 \mathrm{~m} / \mathrm{yr}$ (as in Fig.7). After year 1000, the net evaporation is increased by $7 \%$ and the heat loss to the atmosphere is reduced in $0.4 \mathrm{~W} / \mathrm{m}^{2}$ (new bvalue $5.55 \mathrm{~W} / \mathrm{m}^{2}$ ). Figure $8 \mathrm{~b}$ is a zoom for the first 300 years after the alteration of surface fluxes. Linear trends are fitted to the initial 50 year period.

Figure 9 is the same as in Fig.7 with the difference that in year 1000 the net evaporation and sea surface heat flux are kept constant. Instead, a linear trend of $0.004 \mathrm{psu} / \mathrm{yr}$ is imposed for the Atlantic Water inflowing through the Strait of Gibraltar.

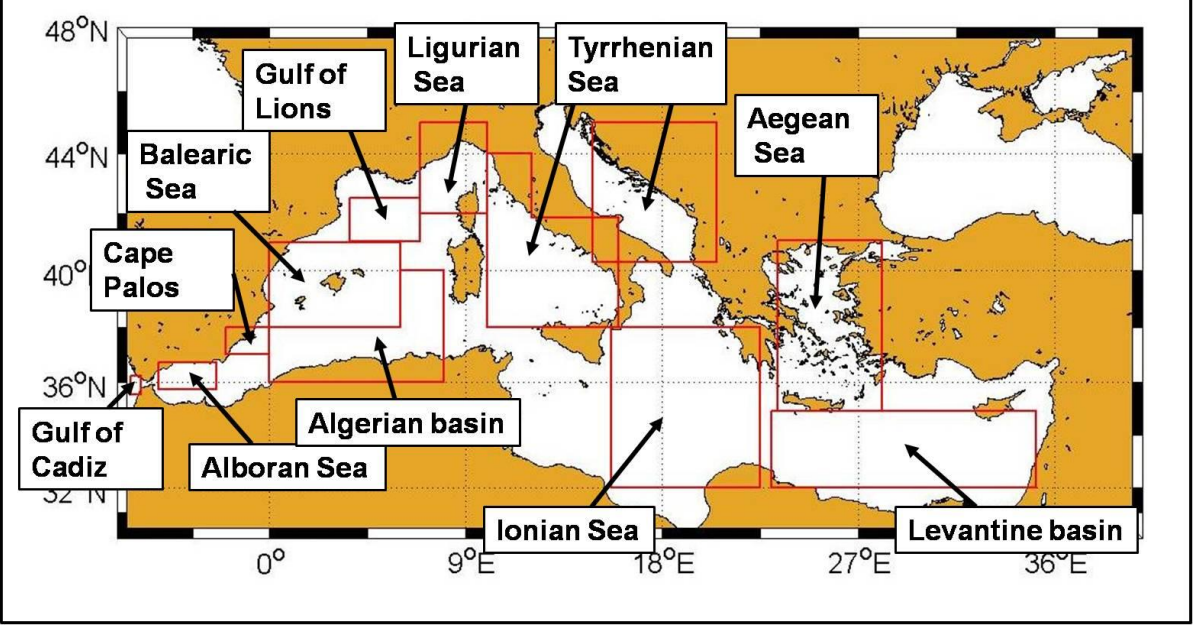

Figure 1. 
Ocean Sci. Discuss., https://doi.org/10.5194/os-2017-50

Manuscript under review for journal Ocean Sci.

Discussion started: 16 August 2017

(C) Author(s) 2017. CC BY 4.0 License.

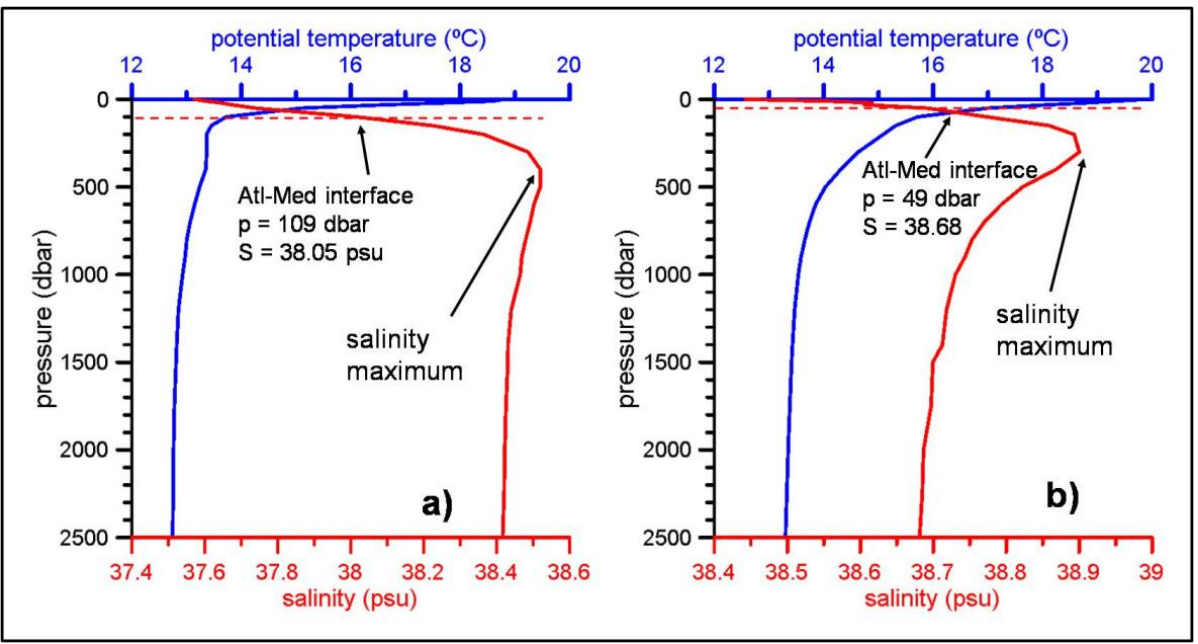

Figure 2.

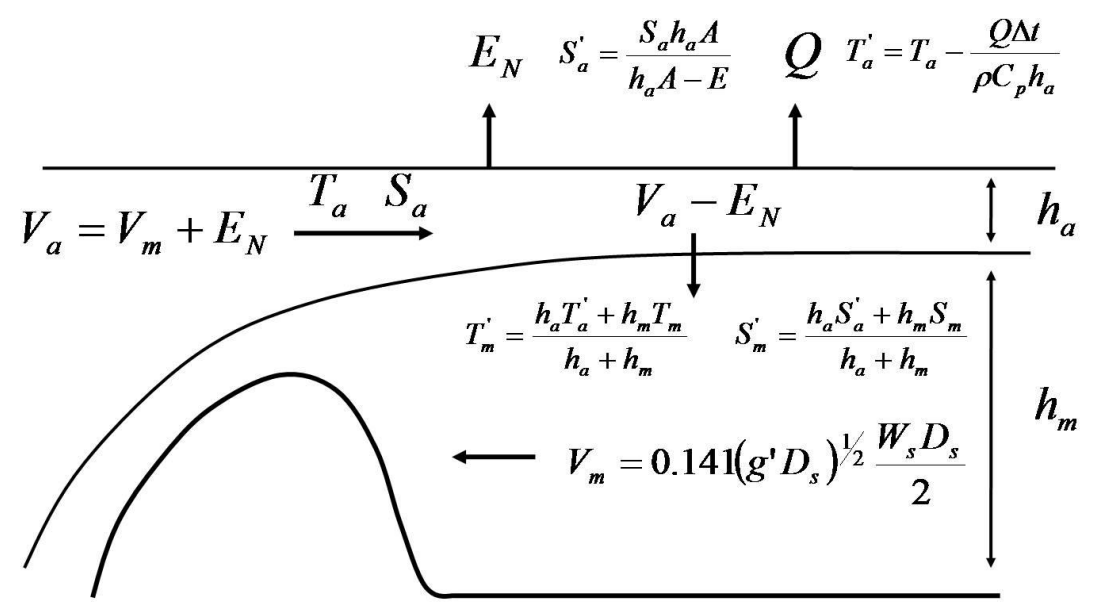

Figure 3. 


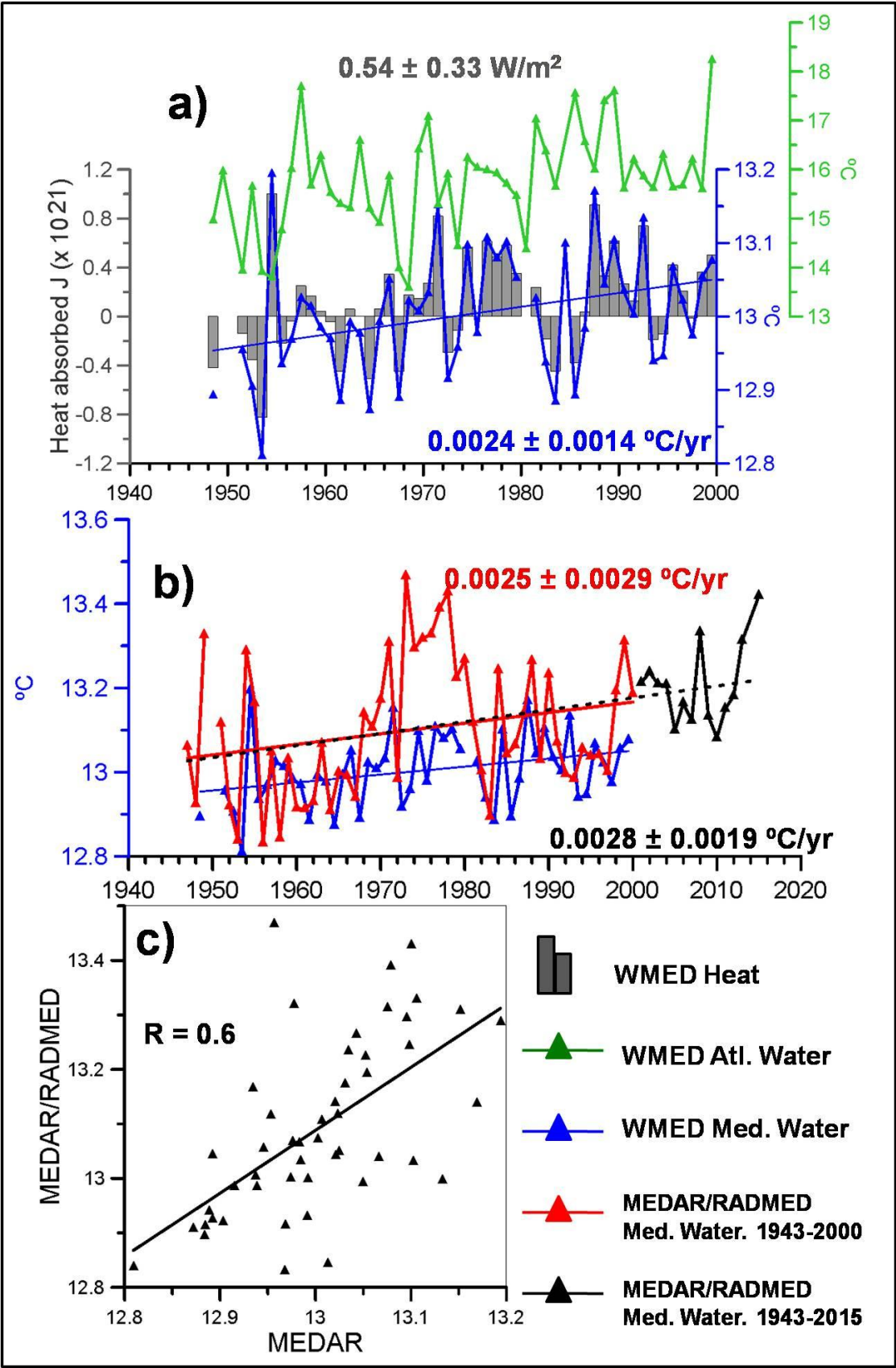

Figure 4. 
Ocean Sci. Discuss., https://doi.org/10.5194/os-2017-50

Manuscript under review for journal Ocean Sci.

Discussion started: 16 August 2017

(c) Author(s) 2017. CC BY 4.0 License.

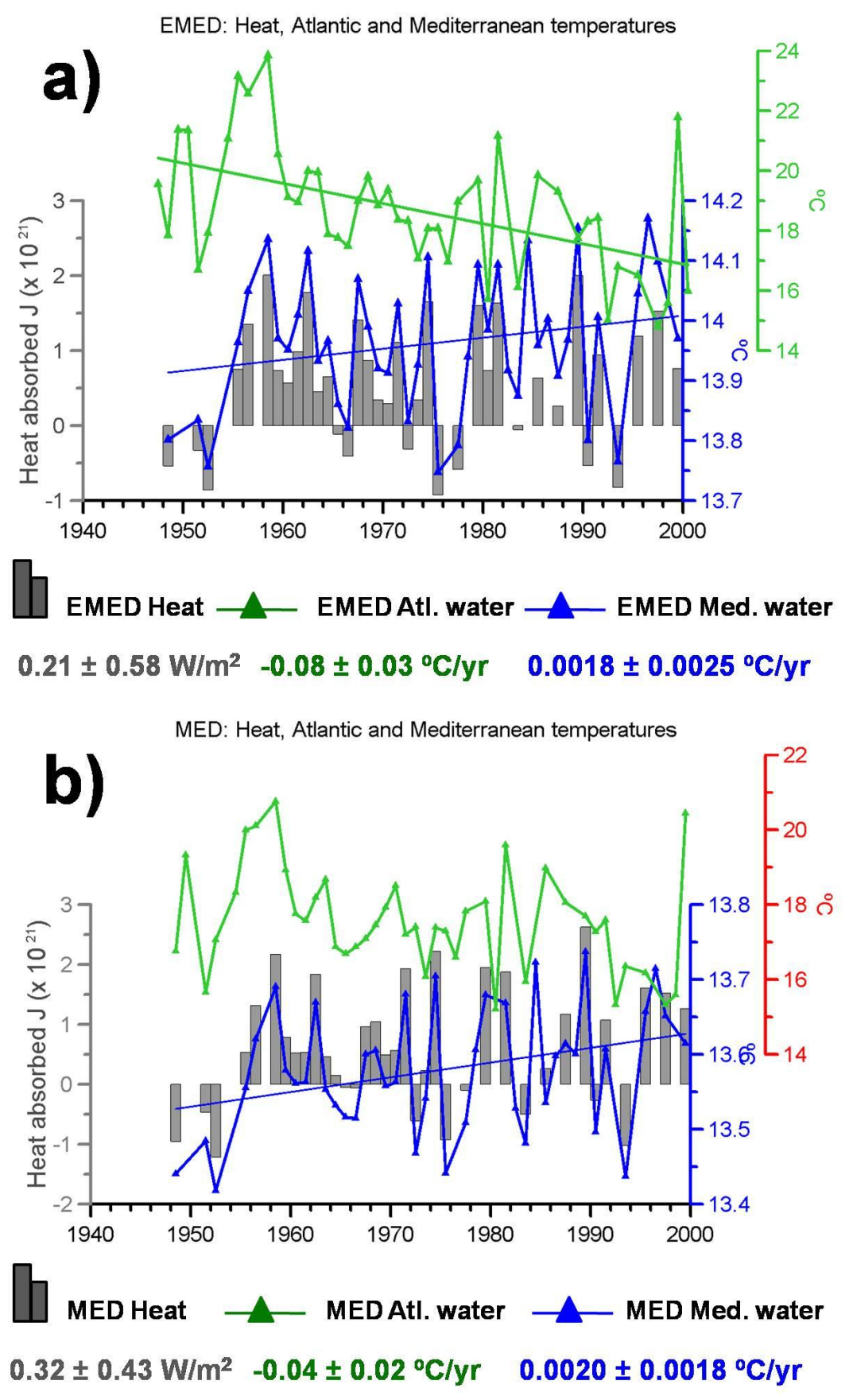

Figure 5. 
Ocean Sci. Discuss., https://doi.org/10.5194/os-2017-50

Manuscript under review for journal Ocean Sci.

Discussion started: 16 August 2017

(c) Author(s) 2017. CC BY 4.0 License.

a)


1943:2000 0.0009 $\pm 0.0004 \mathrm{psu} / \mathrm{yr}$ $1943: 20000.00046 \pm 0.00040 \mathrm{psu} / \mathrm{yr}$ 2000:2015 0.0031 $\pm 0.0016 \mathrm{psu} / \mathrm{yr}$ 1943:2015 0.00052 $\pm 0.00026 \mathrm{psu} / \mathrm{yr}$

b)

EMED: Atlantic and Mediterranean Salinity

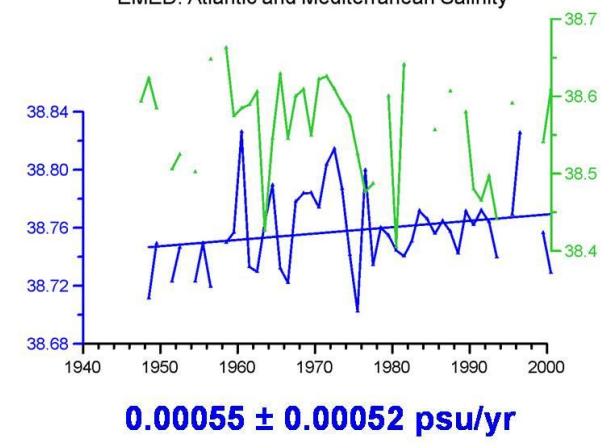

c)

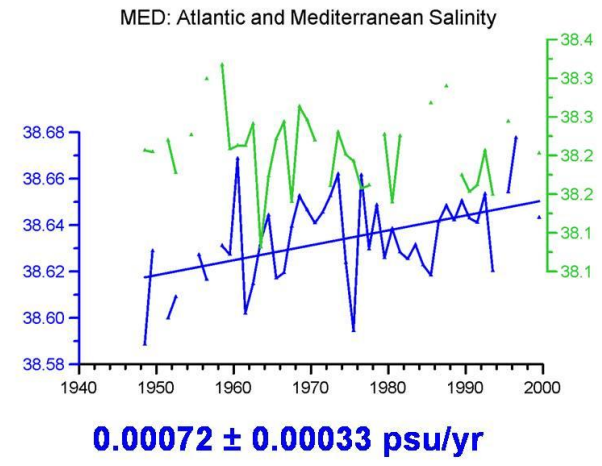

Figure 6. 


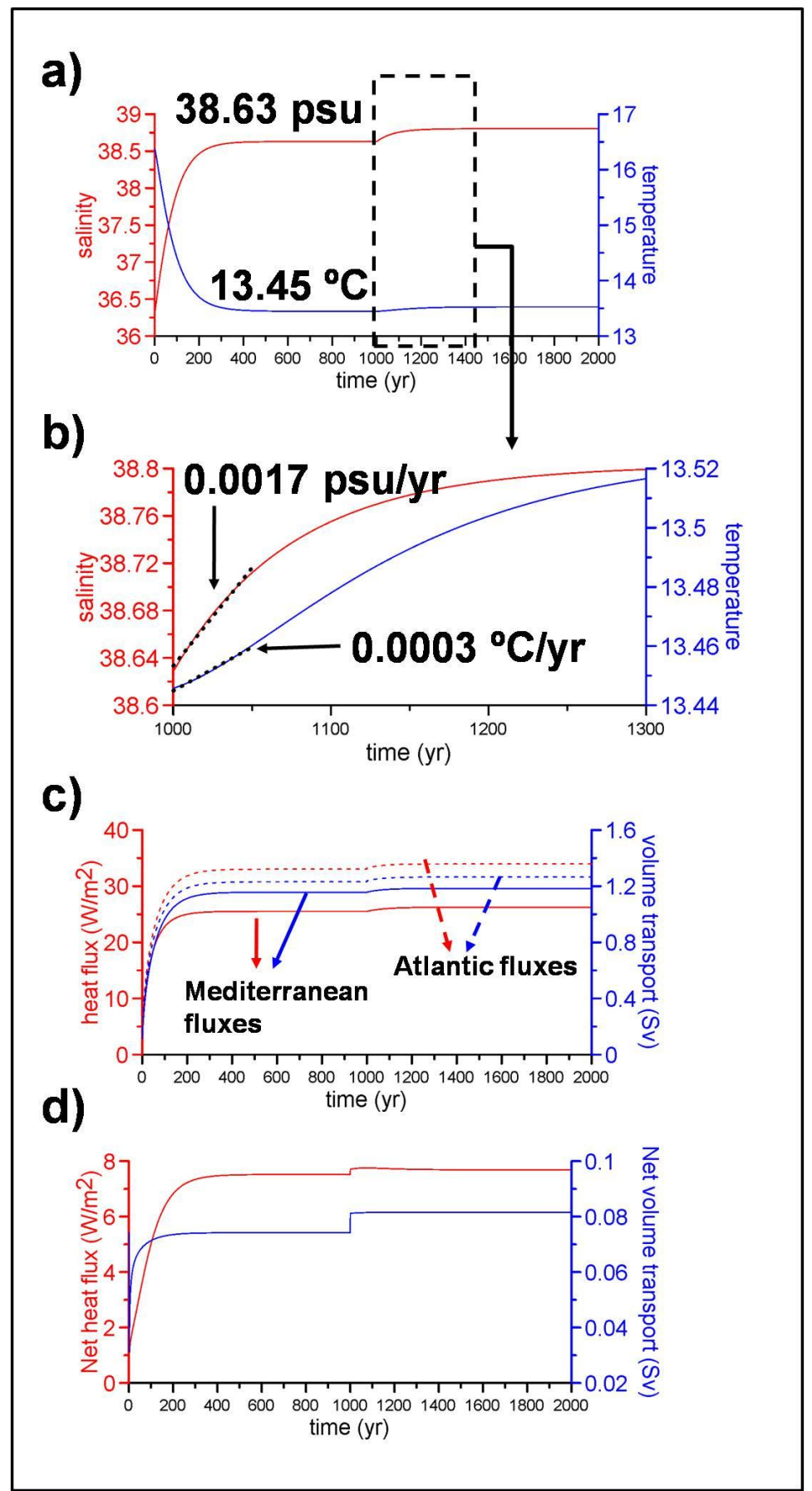

Figure 7. 
Ocean Sci. Discuss., https://doi.org/10.5194/os-2017-50

Manuscript under review for journal Ocean Sci.

Discussion started: 16 August 2017

Ocean Science

(C) Author(s) 2017. CC BY 4.0 License.

Discussions

(c) (1)

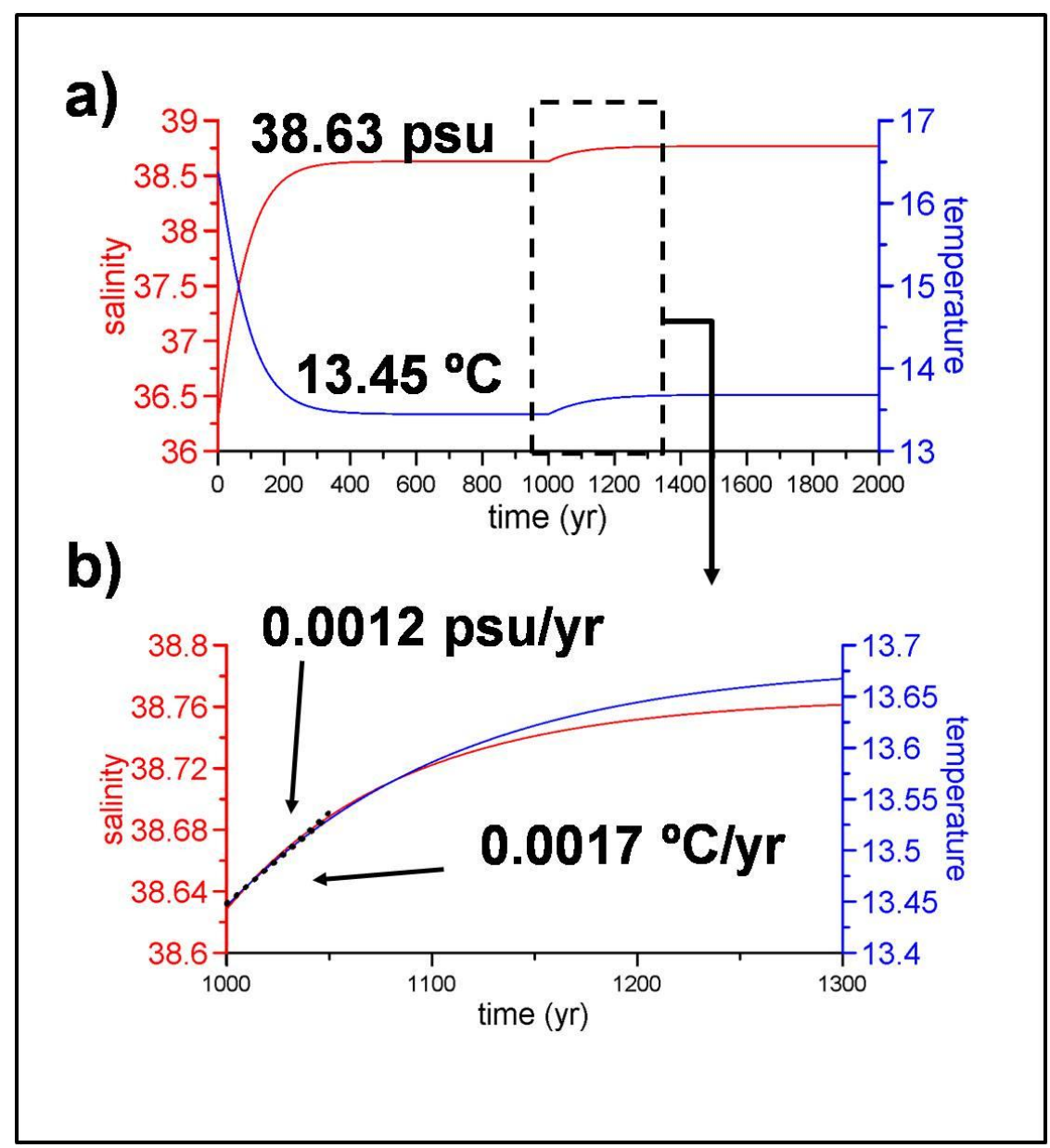

Figure 8. 
Ocean Sci. Discuss., https://doi.org/10.5194/os-2017-50

Manuscript under review for journal Ocean Sci.

Discussion started: 16 August 2017

(C) Author(s) 2017. CC BY 4.0 License.

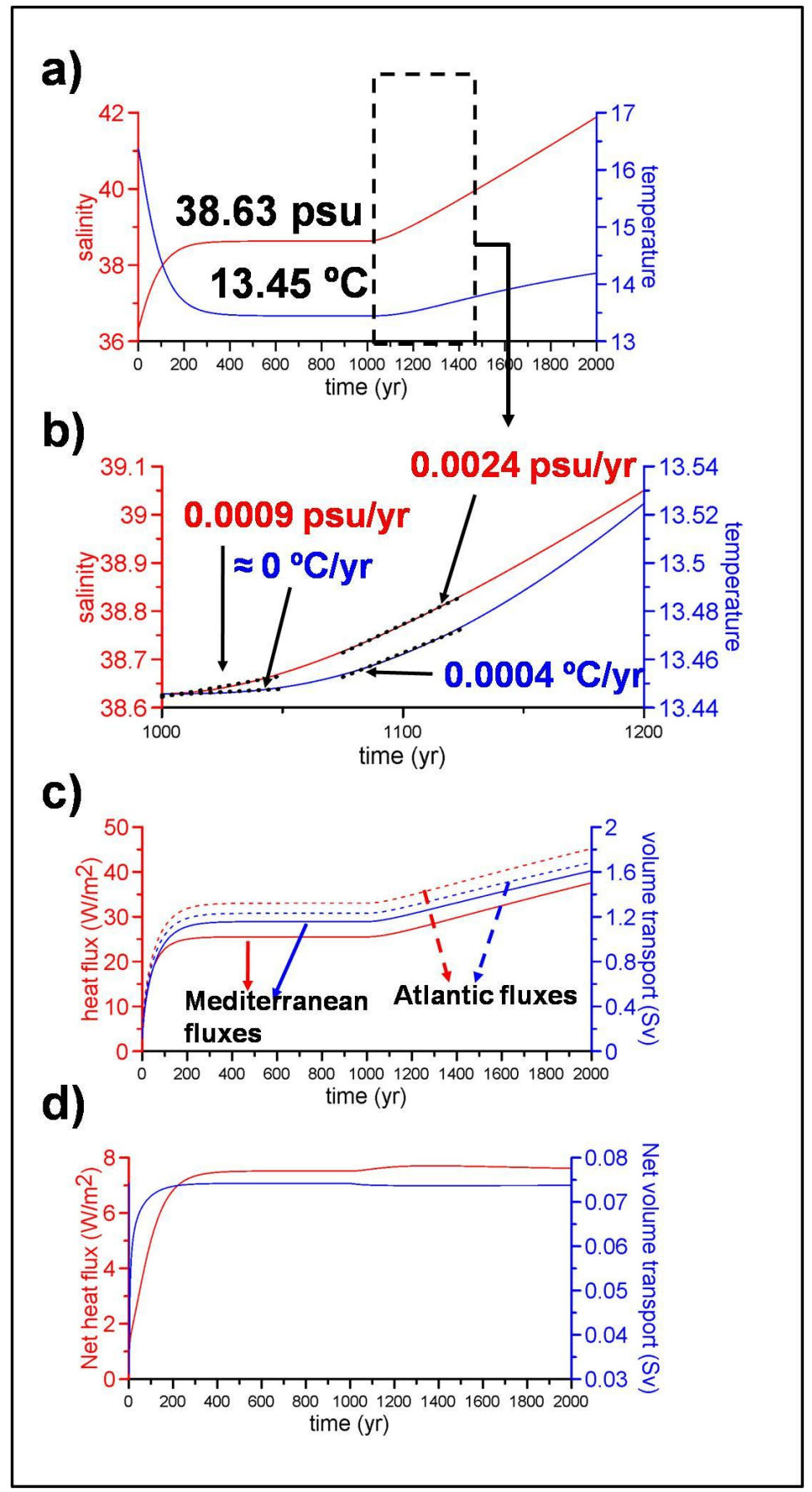

Figure 9. 